\title{
The shadow economy in three Mediterranean countries: France, Spain and Greece. A MIMIC approach
}

\author{
Roberto Dell'Anno • Miguel Gómez-Antonio • \\ Angel Pardo
}

Received: 15 May 2004 / Accepted: 15 April 2006 / Published online: 9 August 2006 (C) Springer-Verlag 2006

\begin{abstract}
This paper offers estimations of the evolution of the shadow economy in three Mediterranean countries, namely France, Spain and Greece. A multiple indicators and multiple causes model based on the latent variable structural theory has been applied. As established by Giles (Working paper on monitoring the health of the tax system, 1995), filtered data to solve the non-stationary problems are used. The model includes the tax burden (both as a whole and disaggregated into direct taxes, indirect taxes and social security contributions), a proxy of regulation burden, the unemployment rate and self-employment as causes of the shadow economy and the GDP growth rate, the labour force participation ratio and the currency ratio as indicators of the underground economy. The results confirm that unemployment, the fiscal burden and self-employment are the main causes of the shadow economy in these
\end{abstract}

This paper has benefited from the comments and suggestions of the anonymous referees. The usual disclaimer applies. The paper was partly written when third author was visiting Real Colegio Complutense at Harvard University. The hospitality of this Institution is gratefully acknowledged.

R. Dell'Anno

Dipartimento di Scienze Economiche e Statistiche, Università degli Studi di Salerno, Via Ponte Don Melillo, 84084 Fisciano (Sa), Italy

M. Gómez-Antonio

Departamento de Economía Aplicada VI, Facultad de Ciencias Económicas y Empresariales, Universidad Complutense de Madrid, Campus de Somosaguas,

28223 Pozuelo de Alarcón, Spain

A. Pardo $(\bowtie)$

Departamento de Economía Aplicada I, Facultad de Ciencias Económicas y Empresariales, Universidad Complutense de Madrid-Real Colegio Complutense at Harvard University,

Campus de Somosaguas 28223 Pozuelo de Alarcón, Spain

e-mail: angel@ccee.ucm.es 
countries, and confirm that an inverse relationship exists between the official GDP growth rate and that of the unofficial economy.

Keywords Shadow economy · Structural equation model

JEL Classification $\mathrm{O} 17 \cdot \mathrm{C} 39 \cdot \mathrm{H} 26$

\section{Introduction}

The effects of the shadow economy (SE) are numerous and important. The SE reduces government revenue and distorts official indicators (growth, unemployment, income distribution, etc.), thereby influencing public sector decisions, producing changes in individual incentives and remuneration factors, etc. As a result, academic and political interest in the SE has greatly increased in the OECD countries in recent years. In this study we estimate the determinants and the size of the SE in three countries (France, Spain and Greece) which share common historical, geographical and cultural roots, but whose recent economic performances are highly varied. These specific countries have been chosen in order to determine if any relationship exists between the level of per capita income and the development of the SE and, additionally, to decide if the causes and indicators are the same in these countries. In line with the proposal of Frey and Weck-Hanneman (1984) multiple indicators and multiple causes models are employed.

The initial problem for researchers into this subject is the definition and consequent understanding of exactly what the SE is. The nature of the SE appears to mean very different things to macroeconomists, labour economists, criminologists, taxation specialists and national revenue accountants. Apparently, no single definition of the underground economy is applicable to all such fields. Several papers have commented upon this problem, notably Schneider and Enste (2000), Giles and Tedds (2002), and Dell'Anno (2003). Although it is impossible to select the best general definition, because the adequacy of taxonomy used must be related to the need to employ a definition and respect the specifications of the econometric model, many authors believe that estimates should represent those productive activities which cannot be directly observed for economic reasons. For example, activities performed with the express intention of avoiding taxes, social contributions which benefit employees or are intended to avoid observing legal requirements concerning minimum wages, working hours, health and safety regulations, etc. ${ }^{1}$

The methods usually applied to estimate the SE may be divided into direct and indirect approaches. Direct methods are based on contacts with or observations of persons and/or firms to gather direct information about undeclared income. There are two types: the auditing of tax returns and surveys. Indirect methods try to determine the size of the hidden economy by measuring

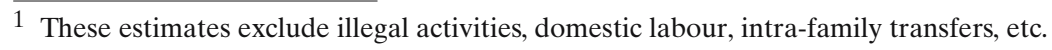


the "traces" it leaves in the official statistics. They are often called indicator approaches and use mainly macroeconomic data. Such methods can be divided into six categories: (1) the discrepancy between national expenditure and income statistics; (2) the discrepancy between the official and real labour force statistics; (3) the transaction approach; (4) the currency demand (or cashdeposit ratio) approach; (5) the physical input (e.g. electricity) method; and (6) the model approach or MIMIC method.

In this paper the MIMIC approach is applied to estimate the evolution of the $\mathrm{SE}$ in France, Spain and Greece. The model or MIMIC approach understands the dimension of the hidden economy to be a "latent variable", and therefore applies statistical modelling, namely structural equation modelling (SEM), commonly employed in social research (psychology, sociology, marketing, etc.) to explore unobservable variables such as attitudes, personality, beliefs, satisfaction, etc. As shown by Schneider and Enste (2000), and similarly argued by Prokhorov (2001, p.17), in the evaluation of the SE these methods generally yield reasonable results which fall within the range of difference between the overestimating macro-methods and the underestimating micro-methods.

We develop a model for France, Spain and Greece because we assume that these countries have common cultural roots as a result of geographical proximity and historical background. Their similarity allows us to employ the philosophy of "ceteris paribus" and, assuming that sociological and historical development evolve identically, to focus exclusively upon the effects of economic variables on the SE in order to determine their importance in each country.

The current paper concentrates exclusively upon economic issues which have a potential relation with the SE, such as the composition of the labour force and gross domestic product (GDP) per capita. We adopt the hypothesis that such variables are different for each country, and therefore believe that by calculating the same econometric framework for each of the three countries we may improve our knowledge of the economic causes of the SE and its development in France, Spain and Greece.

As Schneider (2004) states, Greece has the largest SE in Europe, followed by Italy and Spain, whereas that of France is especially low. Thus, by selecting these countries we can develop a benchmark analysis and highlight the main differences between them. Estimates for these countries can be also found in Schneider (1997, 2005).

Greek shadow economy has also been estimated by Kanellopoulos et al. (1995), who applied a discrepancy method between expenditure and income estimates, and by Tatsos (2001), who used a monetary approach. Analysis and estimates of French underground economy can be found in De Grazia (1983), Barthelemy (1989) and Blank (1994). Spanish hidden economy has been also estimated utilising different methods: Lafuente (1980), Moltó (1980), Mauleón and Sardá (1997), Gómez-Antonio and Alañón (2004), and Gadea and SerranoSanz (2002) (monetary approach); Ruesga (1984) (labour market approach); or Alañón and Gómez-Antonio (2005) (MIMIC approach).

The current paper is organised as follows. In Sect. 2 the Structural Equation Model (SEM) is presented and the MIMIC method is analysed. 
In Sect. 3 the specification of the models and the structural relationships between causes and indicators are discussed, and then identified and estimated in Sect. 4. Our results are presented in Sect. 5 and, finally, our main conclusions are presented in Sect. 6, followed by five statistical appendices.

\section{The structural equation approach and the shadow economy}

The structural equation model consists of statistical relationships among latent (unobserved) and manifest (observed) variables. It implies a structure of the empirical covariance matrix ${ }^{2}$ which means that once the parameters have been estimated, they can be compared to the resulting model-implied covariance matrix. If both matrices are consistent, then the structural equation model is a likely explanation for the relationships among the examined variables. The structural equation models are "regression equations with less restrictive assumptions that allow measurement error in the explanatory as well as the dependent variables" (Bollen 1989). Thus, this method is theoretically superior to regression analysis not only because it explores all the information contained in the covariance matrix, as well as the variance, but also because it allows variables to be measured taking error into account; however, compared to regression and factor analysis, SEM is a relatively unknown tool in economics. ${ }^{3}$

In this paper, we employ one facet of SEM, namely the multiple indicators and multiple causes model. ${ }^{4}$ The first researchers to consider the size of the hidden economy as an "unobservable variable" were Frey and Weck-Hanneman (1984); they introduced the MIMIC model constructed by Zellner (1970), Goldberger (1972), Jöreskog and Goldberger (1975) and others in this field. ${ }^{5}$

This kind of model comprises two types of equations, namely structural equations and the measurement equations system. The equation that captures the relationships between the latent variable $(\eta)$ and the causes $\left(\mathrm{X}_{q}\right)$ is called the structural model, while the equation which links the indicators $\left(\mathrm{Y}_{p}\right)$ with the latent variable (underground economy) is called the measurement model.

\footnotetext{
2 Hence an alternative name for this field is "analysis of covariance structures".

3 The most comprehensive discussions of its applications can be seen in: (Sociology) Bielby and Hauser (1977), (Psychology) Bentler (1986), (Economics) Goldberg (1972), Aigner et al. (1984), Hauser and Sewell (1986), Pindyck and Rotemberg (1993), Brumm and Cloninger (1995), Brandstatter and Brandstatter (1996), Brumm (1997), Baldini and Cherubini (1998), Rettig et al. (1999), Eijffinger et al. (2000), Breitung (2001), Gerpott et al. (2001). For an overview of SEM see Hayduk (1987), Bollen (1989), Hoyle (1995), Maruyama (1997) or Byrne (1998).

4 This belongs to the linear interdependent structural relationships (LISREL)family of models (see Jöreskog and Sörbom 1993).

5 Following Frey and Weck-Hanneman's, other economists have used this approach in a statistical analysis of the "unofficial" economy: Aigner et al. (1988), Helberger and Knepel (1988), Loayza (1996), Pozo (1996), Giles (1995, 1998, 1999a, b), Tedds (1998), Eilat and Zinnes (2000), Cassar (2001), Prokhorov (2001), Giles and Tedds (2002), Chatterjee et al. (2003), Dell'Anno (2003), Dell'Anno and Schneider (2003), Alañón and Gómez-Antonio (2005).
} 
Thus, the SE $(\eta)$ is linearly determined, subject to a disturbance $\zeta$, by a set of observable exogenous causes $x_{1}, x_{2}, \ldots, x_{q}$ :

$$
\eta=\gamma_{1} x_{1}+\gamma_{2} x_{2}+\cdots+\gamma_{q} x_{q}+\zeta
$$

The latent variable $(\eta)$ determines, linearly, and subject to a disturbances $\varepsilon_{1}, \varepsilon_{2}, \ldots, \varepsilon_{p}$, a set of observable endogenous indicators $y_{1}, y_{2}, \ldots, y_{p}$ :

$$
y_{1}=\lambda_{1} \eta+\varepsilon_{1}, y_{2}=\lambda_{2} \eta+\varepsilon_{2}, \ldots, y_{p}=\lambda_{p} \eta+\varepsilon_{p} .
$$

The structural disturbance $\zeta$, and measurement errors $\varepsilon$ all display normal distribution, mutually independent and all variables are transformed to deviations-from-means.

Considering the vectors:

$$
\begin{array}{ll}
\mathbf{x}^{\prime}=\left(x_{1}, x_{2}, \ldots, x_{q}\right) & \text { Observable exogenous causes } \\
\gamma^{\prime}=\left(\gamma_{1}, \gamma_{2}, \ldots, \gamma_{q}\right) & \text { Structural parameters (structural model) } \\
\mathbf{y}^{\prime}=\left(y_{1}, y_{2}, \ldots, y_{p}\right) & \text { Observable endogenous indicators } \\
\lambda^{\prime}=\left(\lambda_{1}, \lambda_{2}, \ldots, \lambda_{p}\right) & \text { Structural parameters (measurement model) } \\
\varepsilon^{\prime}=\left(\varepsilon_{1}, \varepsilon_{2}, \ldots, \varepsilon_{p}\right) & \text { Measurement errors } \\
v=\left(v_{1}, v_{2}, \ldots, v_{p}\right) & \text { Standard deviations of the } \varepsilon \text { 's }
\end{array}
$$

Expressions (1) and (2) can be written as:

$$
\begin{aligned}
& \eta=\gamma^{\prime} x+\zeta \\
& y=\lambda \eta+\varepsilon
\end{aligned}
$$

by assuming ${ }^{6} E\left(\zeta \varepsilon^{\prime}\right)=0^{\prime}$ and defining $E\left(\zeta^{2}\right)=\sigma^{2}$ and $E\left(\varepsilon \varepsilon^{\prime}\right)=\Theta^{2}$, where $\Theta$ is a diagonal matrix with $v$, displayed on its diagonal. ${ }^{7}$ The model can be (pxp) presented for the reduced form as the function of observable variables:

$$
y=\lambda\left(\gamma^{\prime} x+\zeta\right)+\varepsilon=\Pi^{\prime} x+v
$$

The reduced form coefficient matrix and disturbance vector are respectively:

$$
\Pi=\gamma \lambda^{\prime} \quad \text { and } \quad v=\lambda \zeta+\varepsilon
$$

\footnotetext{
6 The assumption of independence between structural disturbance $\zeta$, and measurement errors $\epsilon$ is crucial for the reliability of estimates. Unfortunately, the SEM packages, do not perform this kind of test. Hayduk (1987, p.193) explains that “... is purely a matter of arbitrary convention" and is possible to test this assumption using a model re-parameterisation. An attempt to test the hypothesis of independence between structural and measurement errors is presented in Dell'Anno (2003).

7 In the standard MIMIC model the measurement errors are assumed to be independent of each other, but this restriction could be relaxed (see Stapleton 1978, p. 53). In this analysis, in which a greater number of models are estimated, the covariances between the indicators are often not statistically different from zero. However, in the models where this assumption is relaxed the changes in the estimates of structural coefficients are slight, and therefore the standard restriction is maintained in order to enjoy greater degrees of freedom.
} 
Therefore, the following covariance matrix (model-implied) is obtained:

$$
\hat{\Sigma}=E\left(v v^{\prime}\right)=\sigma^{2} \lambda \lambda^{\prime}+\Theta^{2} .
$$

To facilitate the identification of SEM various conditions are available but, unfortunately, none of these are necessary and sufficient conditions (Bollen 1989).

The necessary (but not sufficient) condition, the so-called $t$-rule, dictates that the number of non-redundant elements in the covariance matrix of the observed variables must be greater or equal to the number of unknown parameters in the model-implied covariance matrix (Bollen op. cit., p. 93). ${ }^{8}$

A sufficient (but not necessary) condition of identification is that the number of indicators must be a minimum of two and the number of causes at least one, provided that a scale to $\eta$ is assigned (following the MIMIC rule). In order to assign a scale to the latent variable it is necessary to fix one $\lambda$ parameter to an exogenous value.

\section{Theoretical background for the choice of variables}

In this section we explain the theoretical model applied to estimate the underground economy, bearing in mind the observation of Duncan (1975), who points out: "The meaning of the latent variable depends completely on how correctly, precisely and comprehensively the causal and indicator variables correspond to the intended semantic content of the latent variable". We agree with Thomas (1992), and believe that the choice of variables is the most relevant limitation of this approach.

As mentioned above, these kinds of models are determined both by various causes of the latent variable and by several indicators. It is usually accepted that the causes include the high tax burden, the share of government employment on labour force, the unemployment rate and self-employment. In our analysis the indicator variables include real GDP, the participation ratio of the labour force and the currency ratio.

Although there is no consensus nor about the causes neither about the indicators of the SE, we believe the use of the set of causal variables and indicator variables listed above is the correct approach to evaluating the development of the shadow economy.

All these variables are linked, in one way or another, to the SE and have previously been used in the partial analysis of shadow economy (e.g. the monetary approach, the labour force methods, etc.). The causal variables employed are usually thought of having a direct and positive effect on the SE i.e. higher levels of unemployment, self-employment, tax burden and, to a lesser extent, the degree of state intervention in the economy imply higher levels of the shadow economy.

\footnotetext{
8 Clearly, the number of observed variances and covariances must be equal to or greater than the number of parameters to be estimated (including variance of latent factor, variances of disturbances, covariances among observed variables, etc.).
} 
On the other hand, the unexpected development of the indicator variables (monetary aggregates, the participation ratio of the labour force and GDP) may reflect that "real economic activity", both in terms of labour and money, differs from the "legal" or official activity.

Therefore, although SE is treated as a latent variable, which by definition is not directly observable, we believe our estimations reflect its development and relative size.

Due to the lack of available information and the unfeasibility of estimating an overly-complex Structural Equation model with regard to the sample size we have not included other potential variables such us the resources governments spend on combating tax evasion, electricity consumption, the indices of corruption and labour market flexibility, etc. ${ }^{9}$

\subsection{Explanatory variables (causes)}

\subsubsection{Tax burden}

According to the relevant academic literature, the most important determinant of tax evasion is the fiscal burden. The generally accepted hypothesis is that an increase in the tax burden provides a strong incentive to work in the unofficial market, and thus a positive sign for the parameter associated to this variable is to be expected. In all MIMIC applications this variable is included as a cause of the underground economy and has historically always exercised a direct effect upon the shadow economy, a fact that the current study confirms.

Within the econometric framework, the tax burden is measured as the total share of all taxes in GDP. This indicator has been also disaggregated into different partial proxies such as direct and indirect taxes and social contributions, as a percentage of GDP, in order to test if all the components of the tax burden have the same effects on the SE.

Theoretical analysis holds that direct taxes and social contributions are more visible than indirect taxes, because indirect taxes suffer from fiscal opacity. Therefore, a positive sign in all the components of tax burden is to be expected, but is greater in the case of direct taxes.

The ratio between tax revenue and GDP is a measure of the effective tax rate. We utilise this rate, instead of the marginal tax rates, because it is the one that is used by the OECD in its international comparisons of the tax burden. The main implication of this choice is that the effective tax rate depends on the breadth of the tax base. Therefore it may change as a result of changes in the tax base while statutory tax rates remain the same and viceversa.

\footnotetext{
9 We estimated models that included also indices published by the Frasier Institute and the Heritage Foundation, e.g. "Size of Government", "Legal System \& Property Rights", "Labor force share with wages set by centralized collective bargaining", "Unemployment insurance", "Labor Market Regulations", "Regulation" and "Index of Corruption". Unfortunately, these time series have an insufficient sample size, inadequate frequency and missing values, which prevent a correct application with the Model approach.
} 


\subsubsection{Public employment upon the labour force}

We have introduced this variable in order to take into account the degree of regulation of the economy. Theoretically, the expected sign for this indicator is ambiguous. Various authors have discovered a negative sign, arguing that, in some industries, the presence of the state could provide a disincentive for people to join the shadow economy. Other papers have described a positive relation, holding that more intensive regulation gives firms a greater incentive to undertake their activities in the underground economy.

Following Aigner et al. (1988), an increase in the size of the public sector and/or the degree of regulation of the economic system, provides an important incentive to participate in the informal economy. However, if greater state intervention in the economy means an intensification of the attack upon tax avoidance or evasion and, in general, upon the shadow or underground economy, if the relevant information was available, we would expect a negative sign. Unfortunately, as stated earlier, there is no data available regarding the struggle to reduce the shadow economy activities.

Therefore, we expect a positive sign for this coefficient, which will support the hypothesis that "more state" in the market, and subsequently an increase in regulation, provides an incentive to operate in the unofficial economy.

\subsubsection{Unemployment rate}

As Giles and Tedds (2002) state, there are two antagonistic forces that determine the relationship between the unemployment rate and the SE. On the one hand, an increase in unemployment could imply a decrease in the black economy as the underground economy could be positively related to the GDP growth rate and the latter is negatively correlated to unemployment. On the other hand, some "officially" unemployed persons spend some of their time working in the black economy (Giles and Tedds, op. cit., p. 127), and thus we may find a positive correlation.

Tanzi (1999, p. 143) writes that “... the relation between the shadow economy and the unemployment rate is ambiguous". He remarks that the labour force in the hidden economy comprises very heterogeneous people: the unemployed and the non-official labour force (retired people, illegal immigrants, minors or housewives) and, furthermore, there are people who have an official and unofficial job at the same time (Tanzi, op. cit., p. 343). In this sense, the official unemployment rate is weakly correlated with the shadow economy. Tanzi (op. cit., p. 343) also states that “... for OECD countries there seems to be a broad relation between the panel data of the size of the underground economy and the official unemployment rates".

Although economic theory does not indicate whether the expected sign of this variable is positive or negative, we believe that there is a positive causal relationship between unemployment and SE, since when unemployment raises many workers have greater incentives to participate in the underground economy. Therefore, we expect a positive sign. 


\subsubsection{Self-employment}

The number of self-employed as a percentage of the labour force is considered to be a determinant of the informal economy. According to Bordignon and Zanardi (1997), a high number of small businesses and a large proportion of independent professionals and self-employed with respect to the total workforce are important characteristics which imply a higher level of the shadow economy. Such workers have greater possibilities for tax evasion as they usually have a greater number of deductible expenses, both from their taxable base and their tax bill in personal income tax. As they work very closely with their clients they can collude with them in the evasion of indirect taxes. Additionally, they find it easier than bigger firms to employ irregular workers since they have fewer internal and external auditing controls. Therefore, ceteris paribus, a high rate of self-employment means a large shadow economy.

\subsection{Indicators}

As argued above, the model approach is superior from a theoretical point of view to other indirect methods because it combines much more information than the others. In the present case three indicators are introduced simultaneously, instead of a single indicator as it happens in most indirect methods.

\subsubsection{Real gross domestic product (variable of scale)}

As we have already mentioned, when using the MIMIC approach we need to fix a scale variable to estimate the rest of the parameters as a function of this scale variable. The value of the fix parameter is arbitrary, but by using a positive (or negative) unit value it is easier to establish the relative magnitude of the other indicator variables. ${ }^{10}$ The choice of the 'sign' of coefficient of scale $\left(\lambda_{11}\right)$ is based on theoretical and empirical arguments.

In the subject literature there is no agreement about the effects of the shadow economy upon economic growth. On the one hand Adam and Ginsburgh (1985), Tedds (1998), Giles (1999b), Giles and Tedds (2002), Chatterjee et al. (2003) and Alañón and Gómez-Antonio (2005) estimate a positive relationship between the official and unofficial economy. In contrast, Frey and WeckHannemann (1984), Loayza (1996), Kaufmann and Kaliberda (1996), Eilat and Zinnes (2000), Ihrig and Moe (2000, 2001, 2004), Schneider and Enste (2000), Dell'Anno (2003) and Dell'Anno and Schneider (2003) find an inverse/negative relationship between these variables.

10 "For instance if the estimate of one of the other elements of $\lambda$ is 3 , then the corresponding indicator variable is 3 times as important as the variable that is the basis for normalisation." Giles and Tedds (2002, p. 109). 
This paper adopts an additional strategy to decide the "right" sign for the relationship between GDP and the latent variable. As in the MIMIC model, if the "sign" of the coefficient of scale $(\lambda)$ is changed, all the structural parameters change signs (keeping the same absolute values and standard errors), it is thus possible to use this factor to resolve this dilemma. The scientific methodology employed is a "reductio ad absurdum". For instance, if a value $(+1)$ is assigned to $\lambda_{11}\left(Y_{1}=\lambda_{11} \eta+\varepsilon_{1}\right.$ : equation of the measurement model), then consequently the estimated structural coefficients show a positive or negative sign. At this point the researcher can verify if these estimated signs agree with economic theories and empirical evidence regarding the underground economy and its causes: if structural coefficients have economic significance then the signs of the reference indicators could be considered to be appropriate. If, however, they entirely contradict well-known theories and empirical studies then the hypothesis that supports the "minus" sign for the relation between the shadow economy and the reference indicator should be accepted. Thus, the hypothesis that supports the "minus" sign for the relation between the shadow economy and growth rate of official GDP is accepted as more reasonable for our analysis. This means that many activities go underground during economic recessions and periods of slow growth. Fixing this variable as the scale variable implies that the effects of the shadow economy are measured in terms official GDP.

\subsubsection{Participation ratio of the labour force}

Some authors have estimated the size of the hidden economy from changes in the labour force participation ratio, the so-called Italian method. A decline in this ratio over time, or a low rate relative to those in comparable economies, may reflect a movement of the workforce from the measured economy into hidden activities. The labour force participation ratio is calculated as the ratio between labour force total (LF) and the population of working age (15-64 years old).

The expected sign for this variable is theoretically ambiguous, since studies of the shadow economy do not agree on whether changes in this ratio reflect changes in the hidden economy. There is, however, a tendency to conclude that people do not withdraw from the measured labour market in order to participate in the hidden economy, since there is evidence that unrecorded economy activity is undertaken by members of the measured workforce. According to Bajada and Schneider (2005), it is possible that the participation ratio, as well as the number of hours worked, may be unaffected by shadow economy activity if such activities are undertaken after official working hours or on weekends, when individuals are not working in the legitimate economy.

Many authors include this variable in their models in order to determine empirically if there is a relationship between this variable and the underground economy. If we find a negative sign, it means that workers are being made redundant and leaving the official labour force and maybe joining the SE. However, 
as our empirical analysis will show, the labour force participation ratio is only a weak indicator for the SE. ${ }^{11}$

\subsubsection{Currency in circulation outside of banks}

This indicator is the basis of the monetary approach to the estimation the size of the shadow economy. It is based on the assumption that irregular transactions use only cash, instead of checks or credit cards, in order to circumvent auditing controls. Hence, if this hypothesis is accepted, it is possible to estimate the hidden economy by comparing the actual demand for cash with the demand that could be expected if the SE did not exist. Thus the expected sign is positive.

In the estimated models the ratio between the time series of the aggregate M1 and M3 is utilised.

\section{Model identification and estimates of the shadow economy}

In order to work with homogeneous data we have used monthly, and halfyearly data from the OECD Statistical Compendium database. These data come from: Economic Outlook Statistics and Projections, OECD Standardised National Accounts and OECD Labour Force Statistics for the three countries; Ministerio de Economía y Hacienda and Boletín de Estadísticas Laborales for Spain; and Le Institut National de la Statistique et des Êtudes Êconomiques for France.

The identification procedure starts from the most general specification (MIMIC 6-1-3) and continues omitting the variables which do not have statistically significant structural parameters ${ }^{12}$ (Fig. 1).

In order to eliminate the non-stationarity: $X_{1}, X_{2}, X_{3}, X_{4}, X_{5}, X_{6}$, are taken as first differences, $Y_{1}$, is converted to the first differences of logarithm, $Y_{2}$ to first differences, and $Y_{3}$ to second differences for France and Spain and to first differences for Greece. ${ }^{13}$

A relevant point, often ignored in previous analyses of the shadow economy using SEM, is the detection of multivariate normality. This assumption is

\footnotetext{
11 In particular, for France and Spain (Tables 2, 3), the coefficients calculated for the restricted models (MIMIC 5-1-2, 4-1-2, etc.) are very similar to the widest specifications (MIMIC 5-1-3, 4-1-3, etc.); however the estimated coefficients for the Greek models, where the participation ratio is excluded, present quite different estimates with respect to the non-restricted specifications (see Table 4).

12 Although the MIMIC approach is able to take into account the relationships between the $X$-variables and between the $Y$ 's, in this analysis we fixed equal to zero the covariances in order to have more degrees of freedom. Our hypothesis is supported by two empirical evidences: (a) the majority of models estimated relaxing previous hypothesis shows that these covariances are often not statistically different from zero; (b) comparing the two alternative MIMIC specification (with and without these covariances), the differences of structural coefficients are slightness.

13 "Usually, [...] one would consider the possibility of cointegration. Unfortunately, there is no established literature to serve as a guide to this procedure in the context of the MIMIC model." Giles and Tedds (2002, p. 128).
} 


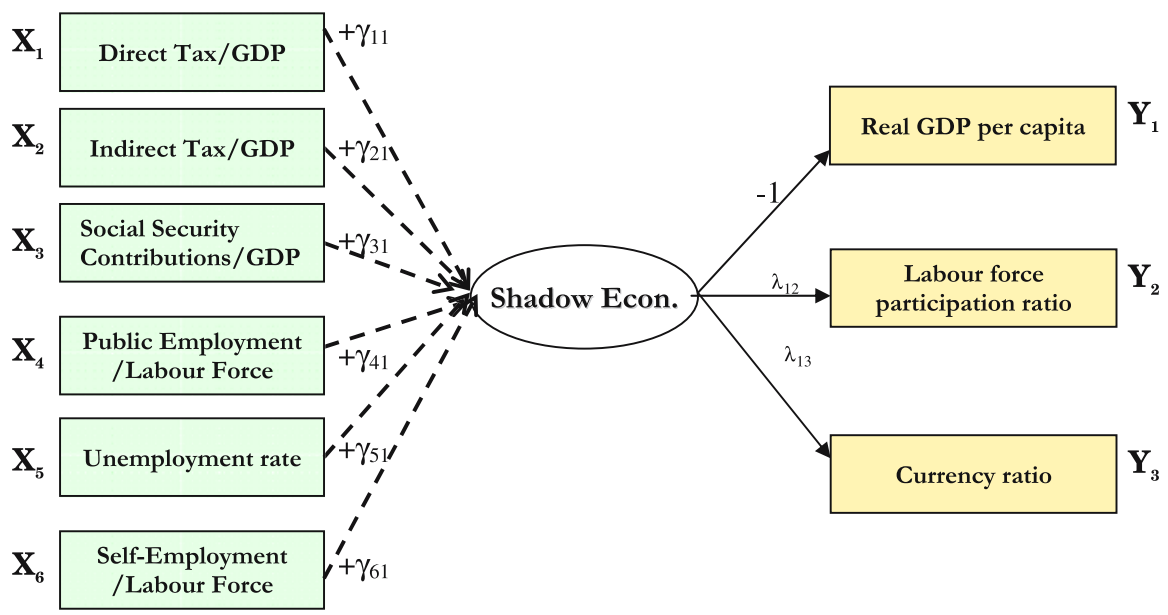

Fig. 1 MIMIC 6-1-3

central to preserve the statistical properties of estimators, as well as the "chisquare" test used to evaluate the fit of models with the dataset. This choice is based on the statistical significance of parameters, the parsimony of specification, the $p$ value of chi-square and the root mean square error of approximation (RMSEA) test. The models are not multinormally distributed and thus when selecting appropriate indicators, applying the maximum likelihood estimator is inherently risky but nevertheless inevitable. ${ }^{14}$ When the variables are not (multivariate) normally distributed, then maximum likelihood estimators may produce biased standard errors and an ill-behaved "chi-square" test of the overall model fit. To determine whether multivariate non-normality is present, Mardia's test $(1970)^{15}$ is used. It is important to emphasise that maximum likelihood estimations are quite robust to several types of violations of multivariate normality (Jaccard and Wan 1996, p. 75).

Given an unacceptable level of non-normality, some adjustments are possible. For example, Bollen (1989) suggests employing another estimator that, in spite of non-normality, maintains asymptotic efficiency i.e. the Generalised (or Weighted) least squares estimator. It is impossible to employ this strategy

\footnotetext{
14 The test statistics for the discrepancy functions associated with maximum likelihood (ML), generalised least squares (GLS), and normal theory weighted least squares (NWLS) are approximately distributed as central chi-square under (I) correct model specification and (II) if the observed variables are multivariate normally distributed. It is well known that when the second assumption is violated, the researcher may prefer the Satorra-Bentler scaled chi-square. We have tried to estimate the MIMIC models for France, Greece and Spain by adjusting the chi-square for the amount of kurtosis in the data. To estimate the S-B chi-square statistic we need to calculate the asymptotic covariance matrix instead of the covariance matrix. Unfortunately by changing the data-based matrix the iterative procedure does not converge and the estimates of the parameters are unreliable. 15 This test is performed by PRELIS 2.53. It provides measures of univariate and multivariate skewness and kurtosis. In addition, a "chi-square" test can be used to check whether there is a statistically significant difference from multivariate normality.
} 
in our analysis as the GLS requires an extremely large sample. A different strategy, also proposed by Bollen is followed, consisting of transforming the time series in order to simultaneously resolve both the non-stationarity and non-multinormality.

In Tables 1, 2, 3 and 4 the estimates of several specifications for the French, Spanish and Greek informal economy are presented. First, in Table 1, a general model which includes four causal variables (tax burden, unemployment, selfemployment and public employment) and three indicator variables (real gross domestic product per capita, currency ratio and labour force participation) is estimated for each country.

\section{Estimation results and simulated effects of economic policies on the shadow economy}

Once the models have been selected and identified, an index of the shadow economy can be constructed by a benchmarking procedure. It is one of the most problematical aspects of the Model approach. It is worthwhile pointing out that there are alternative calibration procedures proposed in this literature: Giles and Tedds (2002), Dell'Anno and Schneider (2003), Tedds (2006) and Bajada and Schneider (2005). Different benchmarking operations are due to diverse economic assumptions about the measurement relationship between observed and unobserved economy. According to our hypothesis, the index of latent variable measures the changes in the size of the SE relative to the size of official GDP. It is because the growth rate of official economy is linked to changes in the SE as percentage of formal GDP (measurement model). With regard to the unit of measure, it is in per cent rate because causes are calculated as ratio (structural model). That being stated, we apply Eq. (7) to estimate the index of SE.

The structural coefficients are multiplied for the "filtered" data for stationary, ${ }^{16}$ and therefore the latent variable is estimated in first differences, since this was the transformation which independent variables underwent before the model was estimated:

$$
\Delta \frac{\hat{\eta}_{t}}{\mathrm{GDP}_{t}}=\hat{\gamma}_{11} \Delta X_{1 t}+\hat{\gamma}_{12} \Delta X_{2 t}+\hat{\gamma}_{13} \Delta X_{3 t}+\hat{\gamma}_{14} \Delta X_{4 t}+\hat{\gamma}_{15} \Delta X_{5 t}+\hat{\gamma}_{16} \Delta X_{6 t}
$$

Subsequently, the index is converted to a "level" time series by integration. ${ }^{17}$ In order to obtain the actual values of the underground economy in terms of official GDP, an a priori known value is required. The exogenous values of Shadow Economy as a percentage of GDP are extracted from Dell'Anno and

\footnotetext{
16 The non-stationary analysis is performed in Appendix C.

17 In this case, where the variables are all differenced to same degree, our method is equivalent to calculate the latent variable multiplying the structural coefficients for raw (unfiltered) data.
} 


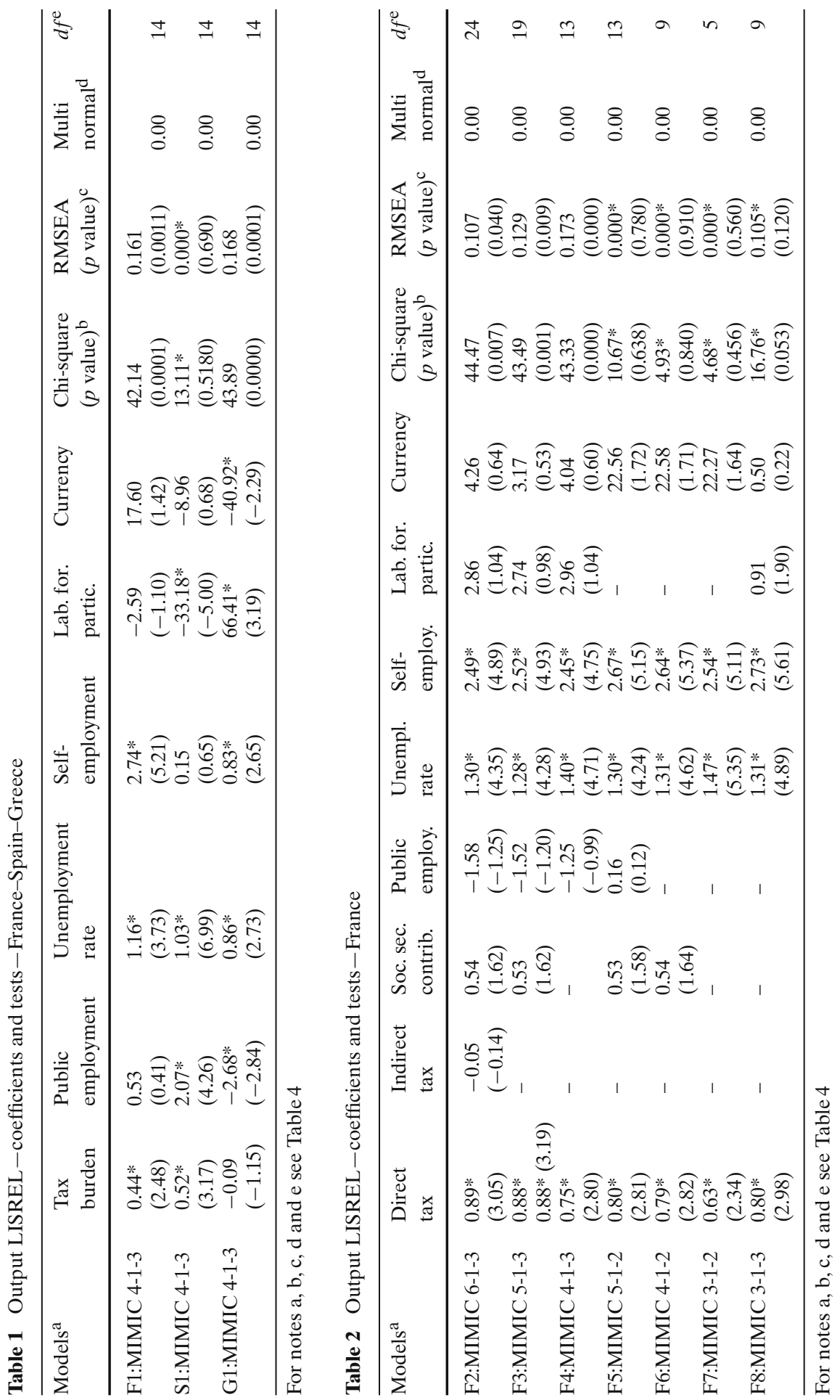




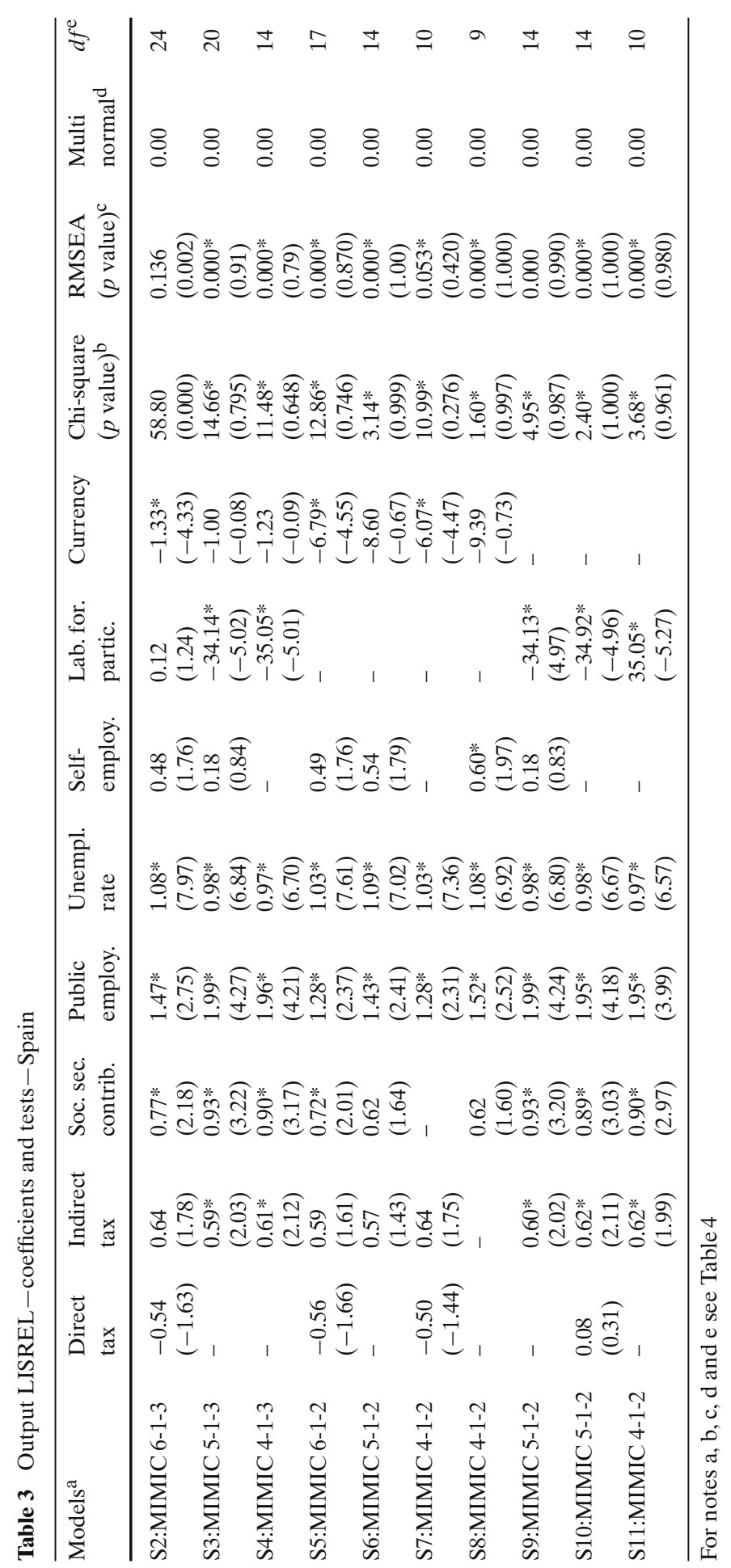




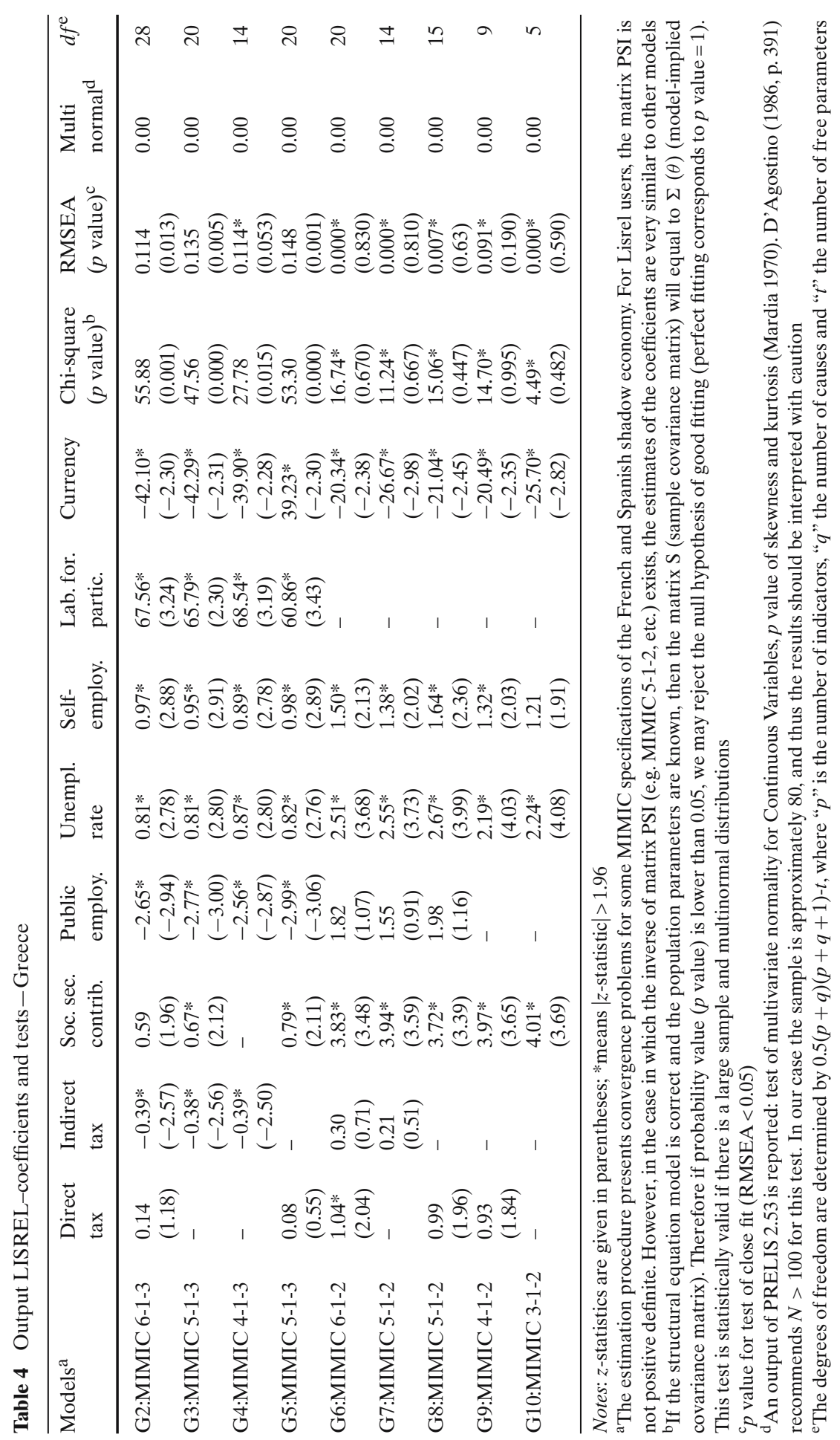


Schneider (2003) for France (14.9\% in the period 1997-1998) and Greece (29\% in the same period); for Spain, the source of exogenous estimation is Alañon and Gómez-Antonio (15.5\% in 1980).

Figures 2, 3 and 4 show the evolution of the shadow economy for France, Spain and Greece ${ }^{18}$ respectively.

Shadow economy shows a decreasing path in France for the whole period analysed, but the reduction of SE is especially important at the end of the sixties and at the end of the eighties. It could be partly due to the evolution of the tax burden. After rising sharply during the 1970s and the first half of the 1980s the tax burden in France has remained broadly at a level of $44 \%$ over the last 20 years (Leibfritz and O'Brien 2005), whereas in Spain and Greece it has doubled during this period. As there is a positive relation between changes in the fiscal burden and changes in the SE this fact could explain the different evolution of this phenomenon between these countries. We also have to take into account that France was the first country to introduce the Value added tax (VAT) formula for the indirect taxes in 1954.

In Spain the evolution of the underground economy is increasing especially during 1974-1986. During this period Spanish fiscal system changed passing from a system with lot of taxes with low taxable bases to a system with few taxes of high taxable bases. After the incorporation of Spain in the European Economic Community the underground economy is in the range $24-30 \%$. As the model stated one of the main causes of SE in Spain is the indirect taxation what is ratified by the evolution of the index. The implementation of the European VAT in Spain seemed to slow down the growth of the Shadow economy.

The evolution of the Geek index is quite erratic and we have to interpret it with caution. We have to take into account as Christopoulos (2003) stated, that Greek National accounts have been revised by inflating them approximately by $28 \%$ since 1988, this fact can help to explain the erratic trend of the underground economy as a percentage of GDP in Greece.

The results for Greece, although statistically significant, should be interpreted carefully, due to the unexpected signs for several variables (e.g. the tax burden is not significant when used as an aggregate, the currency ratio inversely related to shadow economy. ${ }^{19}$ ) In addition, it should be emphasised that the estimation of the parameters is unreliable compared to alternative model specifications. ${ }^{20}$

As shown in Table 5, the differences in GDP per capita between France, which displays a decreasing shadow economy, and Greece and Spain, whose shadow economies are rising, are highly significant over the period of time

\footnotetext{
18 Although it is not robust enough, we have included the Greek shadow economy index in order to compare it to those of France and Spain.

19 Our theoretical hypotheses assume that most participants in the hidden economy prefer to pay in cash instead of using credit cards or checks or other means of payment which are more transparent to the fiscal authorities. Thus, the shadow economy and currency in circulation should be positively correlated

20 See Table 4, which compares cases including and excluding labour force participation.
} 


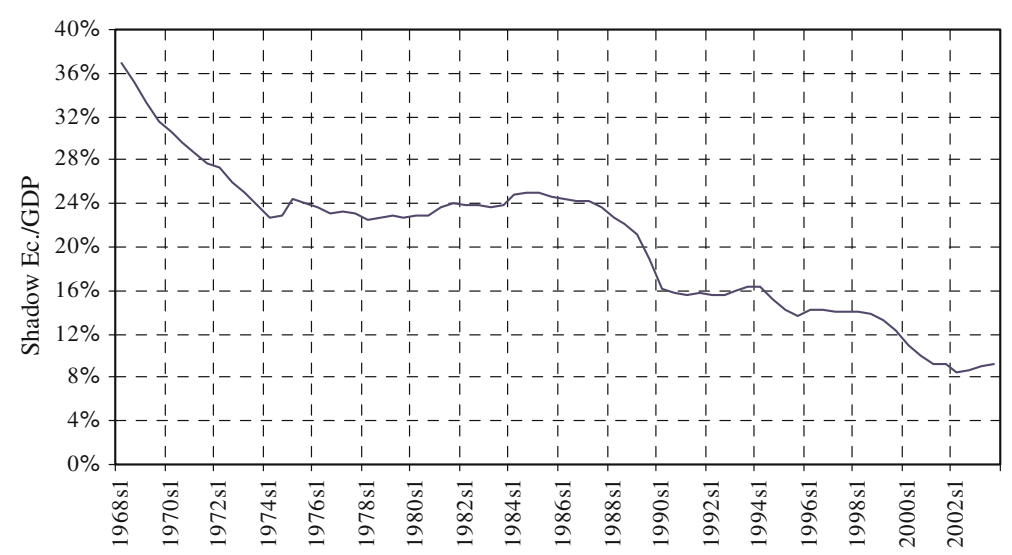

Fig. 2 Shadow economy index: France-(F7)

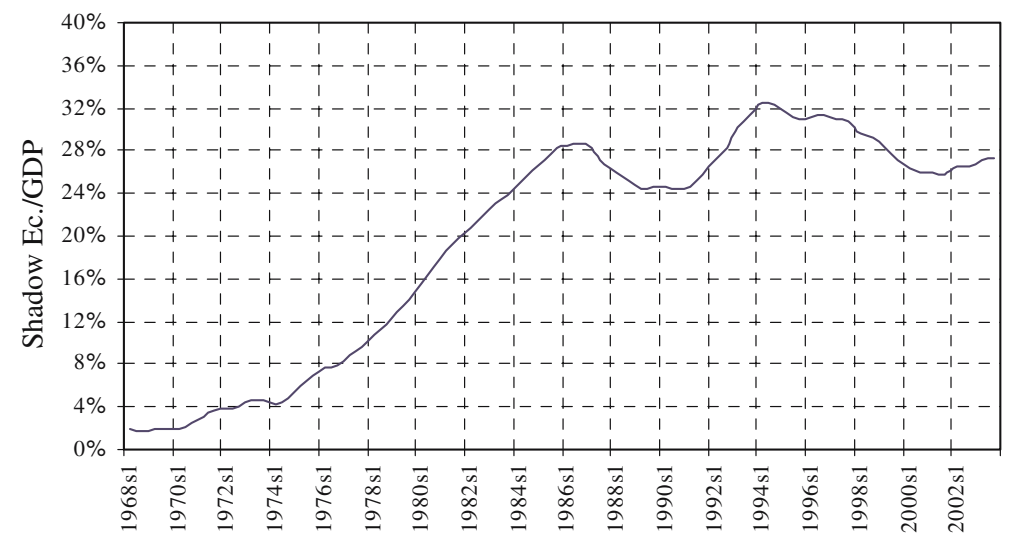

Fig. 3 Shadow economy index: Spain -(S11)

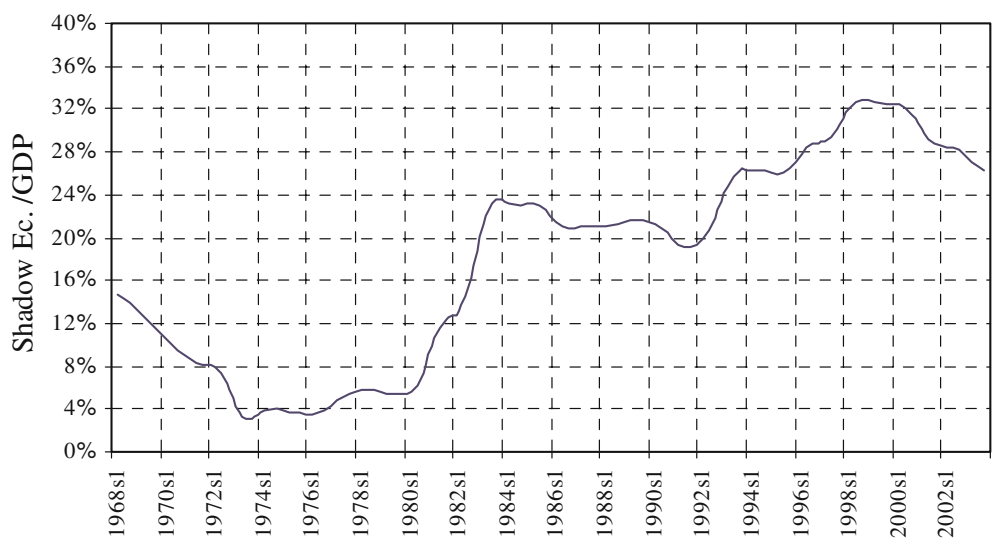

Fig. 4 Shadow economy index: Greece-(G10) 
Table 5 GDP per capita at current market prices and PPS; relative level EU15=100 and shadow economy as a ratio of GDP

\begin{tabular}{llrlrlr}
\hline & France & \multicolumn{3}{c}{ Spain } & \multicolumn{3}{c}{ Greece } \\
\hline $1967-1976$ & 108 & $28.5 \%$ & 75 & $3.9 \%$ & 65 & $8.2 \%$ \\
$1977-1986$ & 109 & $23.7 \%$ & 73 & $19.6 \%$ & 67 & $13.8 \%$ \\
$1987-1991$ & 107 & $19.6 \%$ & 75 & $25.5 \%$ & 59 & $20.8 \%$ \\
$1992-1996$ & 105 & $13.6 \%$ & 79 & $29.3 \%$ & 64 & $28.3 \%$ \\
2002 & 103 & $8.6 \%$ & 84 & $26.5 \%$ & 67 & $28.4 \%$ \\
\hline
\end{tabular}

Source: EUROSTAT (2003)

Table 6 Comparison between different shadow economy estimates

\begin{tabular}{|c|c|c|c|c|c|c|c|c|c|}
\hline \multirow[t]{2}{*}{ Countries } & \multicolumn{3}{|c|}{ France } & \multicolumn{3}{|l|}{ Spain } & \multicolumn{3}{|c|}{ Greece } \\
\hline & 1990 & 1995 & 2000 & 1990 & 1995 & 2000 & 1990 & 1995 & 2000 \\
\hline Our esti & 16.0 & 14.0 & 10.5 & 24.5 & 31.2 & 26.2 & 20.9 & 26.1 & 31.9 \\
\hline Schneider ${ }^{\mathrm{a}}$ & 9.0 & 14.5 & 15.2 & 16.1 & 22.4 & 22.7 & 22.6 & 28.6 & 28.7 \\
\hline Schneider and Enste ${ }^{b}$ & 12.3 & - & - & 22.9 & - & - & 21.8 & - & - \\
\hline Lacko (1990-1993 average) $)^{\mathrm{c}}$ & 12.1 & - & - & - & - & - & 21.8 & - & - \\
\hline Johnson et al. (1990-1993 average $)^{d}$ & 10.4 & - & - & - & - & - & 27.2 & - & - \\
\hline Gómez-Antonio and Alañón ${ }^{\mathrm{e}}$ & - & - & - & 19.8 & 20.1 & 20.9 & - & - & - \\
\hline
\end{tabular}

Source: ${ }^{\mathrm{a}}$ Schneider (2005); ${ }^{\mathrm{b}}$ Schneider and Enste (2000); ${ }^{\mathrm{C}}$ taken from Schneider and Enste (2000); d Johnson et al. (1998a, b); ${ }^{\mathrm{e}}$ Gómez-Antonio and Alañón (2004)

analysed. However this hypothesis is only tentative, since further research is needed to test it. These results are in line with the ones obtained by other researchers using diverse methodological approaches (Table 6).

With regard to reliability of MIMIC estimates, it is a controversial matter and the scientific debate is in progress. To summarise, the main obstacles meet applying this approach are: (1) to be fully confident that the real meaning of the latent variable is the shadow economy instead of another similar variable; (2) to apply the SEM approach to small sample sizes and time series analysis; (3) to convert the index calculated by structural model in actual values of SE; (4) to calculate the confidence intervals associated with estimates of the latent variable; (5) to test the hypothesis of independence between structural and measurement errors; (6) to precisely identify the properties of the residuals; (7) to consider that the outcomes are independent of the (exogenous) choice of the coefficient of scale $(\lambda)$.

With reference to the last criticism (7), known as the "identification problem" in the literature on structural simultaneous equation systems, it has effect on the values of the estimated structural coefficients, hence, in the index of the shadow economy. In fact, by changing the normalisation value $\left(\lambda_{11}\right)$, all estimated coefficients change proportionally; in other words, $\hat{\gamma}_{q}=\gamma_{q}^{*} / \lambda_{11}$, where $\hat{\gamma}_{q}$ indicate the estimated coefficients and $\gamma_{q}^{*}$ represent the "not-definite-scale" coefficients. Previous relationship means that all parameters are unique, up to a scalar multiplication, or, alternatively, that we can estimate infinite parameters, 
Table 7 Simulated effects of economic policies on the shadow economy

\begin{tabular}{|c|c|c|c|c|c|c|}
\hline \multirow[t]{2}{*}{ Causes } & \multicolumn{2}{|l|}{ France } & \multicolumn{2}{|l|}{ Spain } & \multicolumn{2}{|c|}{ Greece } \\
\hline & $\overline{e_{2003}}$ & Level effect & $\overline{e_{2003}}$ & Level effect & $\overline{e_{2003}}$ & Level effect \\
\hline Direct tax/GDP & $8.1 \%$ & 0.63 & - & - & - & - \\
\hline Indirect tax/GDP & - & - & $4.4 \%$ & 0.62 & - & - \\
\hline Soc. sec. contrib./GDP & - & - & $2.9 \%$ & 0.90 & $20.5 \%$ & 4.01 \\
\hline Public empl./lab. force & - & - & $4.8 \%$ & 1.95 & - & - \\
\hline Unemployment rate & $14.5 \%$ & 1.47 & $4.3 \%$ & 0.97 & $7.8 \%$ & 2.24 \\
\hline Self-empl./lab. force & $29.9 \%$ & 2.54 & - & - & $18.6 \%$ & 1.21 \\
\hline
\end{tabular}

all of which are proportional to the coefficient of scale, with identical statistical properties.

These criticisms suggest that extreme caution should be employed when considering the absolute values of the estimates of the underground economy, which are shown in the following section and that more attention should be paid to the dynamics of the indexes calculated.

In Table 7 are shown the simulated effects in the SE ratio for the 2003 associated to changes in estimated relevant causes of shadow economy in each country. ${ }^{21}$

The first column is an elasticity. It measures the percentage change in the SE ratio that arises from a change in each cause of $10 \%$ and it is calculated as follows:

$$
e_{t}=\frac{\left(1-\frac{\hat{\eta}_{t}}{\eta_{t}}\right)}{\left(1-\frac{\hat{x}_{q t}}{x_{q t}}\right)}
$$

where $\hat{x}_{q t}=0.9 * x_{q t}$, and $\hat{\eta}_{t}$ is the simulated SE when one of the causes is equal to $\hat{x}_{q t}$.

The second column measures the percentage change in the SE ratio that arises from a change in the level of each cause of 1-percentage point (level effect). These values are the structural coefficients exposed in the Tables 2, 3 and 4).

According to these simulated effects the most effective way of controlling for the growth of shadow economy would be, ceteris paribus, through policy measures which reduce unemployment and also implementing other measures aimed to reduce and to prevent tax avoidance and underground activities carried out by the self-employed.

\section{Conclusions}

In this paper, we have estimated MIMIC models to measure the size and the evolution of the shadow economy in three Mediterranean countries: France,

21 In the Appendix E are exposed empirical outcomes for each country in greater details. 
Spain and Greece. As the SE is a very complex phenomenon, we have found different causes for the existence of shadow economy in each of these countries, and thus further research is required.

We believe that estimates of SE should be considered always an approximation, rather than exact measures and, consequently, the economic policies resulting from these figures need to be used cautiously and with a full understanding of their limitations. Nevertheless, our principal conclusions could be summarised as follows.

Whereas in the French case the shadow economy is declining, the submerged economy in Spain and Greece is on increase. This difference may be due to the level of development of these economies, since richer economies may have less incentives or possibilities to go underground than lesser-developed ones. Although we have concentrated on the tax burden as one of the main causes of the shadow economy, the economic agents in a relatively underdeveloped country with regressive taxes and unenforced regulations could also have stronger incentives to participate in the underground economy e.g. low incomes and insufficient public goods and services.

Results show that French shadow economy presents a decreasing path, from $36 \%$ of GDP in 1968 to approximately 9\% in 2002. Developments in Spain have followed a completely opposite direction. Before 1977 underground economy was insignificant, due to the characteristics of the Spanish fiscal system. The change from a Latin tax system towards an European one caused an increase on the hidden economy from 9 to $26 \%$ of GDP in 2002. The evolution of the Greek SE must be interpreted with caution, but it has risen from $8 \%$ in 1980 to $28 \%$ in 2002.

In the French case all the causal variables included are significant except for the public employment ratio, which can be interpreted as that French regulations are "fair" and therefore do not influence economic agents to go underground. The sign of the unemployment rate is positive, and thus appears to be a direct cause of the growth of the shadow economy. When the fiscal burden is broken down, the direct tax burden is the most important component in France, whereas in Spain and Greece the principal component of the tax burden, in terms of the effect upon the SE is social security contributions.

Table 2 shows that the influence of the tax burden in the French shadow economy is caused by direct taxation, since neither Social Security contributions nor indirect taxes coefficients are significant. The indicator of the labour force participation ratio is also significant and positive, indicating that there is no flow of resources between the official economy and the hidden economy. The self-employment variable is always significant in all the models, and the expected positive sign is one of the principal causes of the shadow economy in this country.

Our recommendation for French policy-makers is to implement reforms in order to combat direct tax evasion and increase controls upon the self-employed collective. Leibfritz and O'Brien (2005) recommend the widening of the tax base both of the personal income tax, which is highly progressive but has a narrow base, and the corporate tax and simplifying the tax system, since it is complex 
and administrative costs are high. However the level of the French shadow economy is not particularly high when compared to other OECD countries.

In the Spanish case the results show that all the variables show the sign predicted by the theory. Unemployment is confirmed as a key cause of the shadow economy, as described by Ahn and De la Rica (1997) and Alañón and GómezAntonio (2005). As can be seen in Table 3, direct taxation is not an important cause of the hidden economy in Spain, whereas Social Security contributions and indirect taxation coefficients are significant. The remaining causes of the hidden economy in Spain are public employment, which displays a positive sign and suggests that economic regulation or some state intervention both produce and affect the shadow economy. Surprisingly, although self-employment is thought to be closely related to the shadow economy in Spain, this variable is not statistically significant. This unexpected result may possibly be explained by the fact that many participants in the shadow economy are in fact self-employed, but are registered as salaried workers and perform shadow economy activities outside of their official working hours. An alternative explanation may be that in Spain the self-employed may choose to have their incomes taxed indirectly, whereby taxes are lower than by direct estimation of profits. Such favourable tax treatment may induce the self-employed to remain visible and transparent, instead of going underground.

Thus, we believe that, in the case of Spain, social security contributions should be reformed in order to make the labour market more flexible and combat the evasion of indirect taxes, while over-regulation and excessive bureaucracy need to be drastically reduced.

Unlike the French and Spanish cases the tax burden, in general, is not significant in the case of Greece. When this variable is disaggregated into direct taxation, indirect taxation and social security contributions, only the latter are significant in most models.

Although we have stated above that Greek results should be interpreted carefully, our econometric analysis suggests the following conclusions. ${ }^{22}$ The best Greek model in terms of fit is G10, where only social security contributions, the unemployment rate and self-employed causal variables are significant. These results may indicate that Greek regulations and the tax burden are weaker than in the Spanish and French cases, since neither direct nor indirect taxation nor public employment are significant causes of the SE. The fiscal system in Greece is very different from Spain and France. Indirect taxes are more important than direct ones, and this probably explains the obtained results. Tax evasion is much simpler in Greece than in France or Spain, as it is easier to avoid indirect taxes than direct ones. The sectorial composition of the labour force could also help to explain the differences in the behaviour of the shadow economy since agriculture and related industries employ a high proportion of undeclared workers. Whereas the participation of the labour force in agriculture in France and Spain is low, $50 \%$ of Greek workers are employed in this sector.

22 We must also take into account the procedure opened by the European Commission concerning the reliability of Greek statistics in the period prior to entry in the European Monetary Union. 
Thus, in the case of Greece, since estimation results were strange and not highly significant, we recommend labour market and tax system reforms. Labour market should be flexibilised in order to reduce unemployment. The fact that taxation do not seem to be a shadow economy cause in this country may mean that there is still room to collect more taxes. It could be due both to a nonefficient tax system and to a no too high burden tax.

According with a cross-national approach, the main conclusions reached after empirical analysis are the following. Unemployment is one of the main causes of the shadow economy. This coefficient presents a positive sign in each model and for each country, and is particularly important since workers in the submerged economy are a dual burden for the State. On the one hand, a percentage of unemployed workers who go underground receive social benefits, and, on the other, if these shadow economy activities became legal, then both companies and workers would pay taxes.

There is empirical evidence that a positive relationship exists between the size of the shadow economy and the self-employment indicator, which demonstrates that this variable is one of the principal contributors to the growth of the shadow economy, irrespective of the level of economic development.

The key role of unemployment and the self-employed in the shadow economy activities are also underlined by the simulated effects of economic policy in shadow economy.

Social contributions are a significant determinant of the shadow economy for Greece and Spain but, surprisingly, are not so in the French case. It could be due to the fact that the share of social security contributions in GDP declined since the mid-1980s, although further reductions for low paid workers should be implemented (Leibfritz and O'Brien 2005). It means that labour market regulations can be considered as another cause of the unofficial economy in Spain and Greece. Thus, policymakers in these countries should reform social contributions in order to make the labour market more flexible and limit the growth of the underground economy.

The effects of the various components of the tax burden upon the shadow economy are different in each country. The tax burden is a fruitful area for reform as the size and development of the shadow economy are apparently closely related to the structure and composition of the tax system. From our results, it may be derived that in a highly-developed tax system economic agents perceive more clearly the real taxes which they pay.

The results obtained for these countries may indicate that their economic performances, measured in terms of growth rate of real GDP per capita, seems to be a plausible explanation of the changes in shadow economy. Low growth rate of per capita incomes and insufficient provision of public goods and services (education, health, social security, etc.) may foster the need for additional (undeclared) sources of income.

An important additional policy conclusion may be drawn from the evidence that the coefficient of the official GDP and shadow economy $(\lambda)$ is negative. When the official economy expands, it encourages underground activities to move "above ground". Summing up, policy measures aimed to increase labour 
market flexibility, simply administrative and fiscal procedures, reform the welfare benefits system, increase the quality o public services, or facilitate access to the banking system are strongly recommended. Such measures would both improve the efficiency of the market economy and encourage shadow economy activities to become official.

\section{Appendix A: Data sources}

Table 8 Data sources

\begin{tabular}{|c|c|c|c|}
\hline Var. & Causes & Sources & Annotations \\
\hline$X_{1}$ & Total direct tax/GDP & $\begin{array}{l}\text { OECD statistical } \\
\text { compendium database }\end{array}$ & Semi-annual frequency \\
\hline$X_{2}$ & $\begin{array}{l}\text { Social Sec. contrib. received } \\
\text { by Government /GDP }\end{array}$ & $\begin{array}{l}\text { OECD statistical } \\
\text { compendium database }\end{array}$ & Semi-annual frequency \\
\hline$X_{3}$ & Total indirect tax/GDP & $\begin{array}{l}\text { OECD statistical } \\
\text { compendium database }\end{array}$ & semi-annual frequency \\
\hline$X_{4}$ & $\begin{array}{l}\text { Employment, } \\
\text { government/labour force }\end{array}$ & $\begin{array}{l}\text { OECD statistical } \\
\text { compendium database }\end{array}$ & Semi-annual frequency \\
\hline$X_{5}$ & Unemployment rate & $\begin{array}{l}\text { OECD statistical } \\
\text { compendium database }\end{array}$ & Semi-annual frequency \\
\hline$X_{6}$ & $\begin{array}{l}\text { Self-employment/labour } \\
\text { force }\end{array}$ & $\begin{array}{l}\text { OECD statistical } \\
\text { compendium database }\end{array}$ & Semi-annual frequency \\
\hline \multicolumn{4}{|c|}{ Indicators } \\
\hline$Y_{1}$ & $\begin{array}{l}\text { Real gross domestic } \\
\text { product per capita }\end{array}$ & $\begin{array}{l}\text { OECD statistical } \\
\text { compendium database }\end{array}$ & $\begin{array}{l}\text { [GDP market price value/deflator } \\
\text { of GDP]/population in working } \\
\text { age (15-64 years old); } \\
\text { Semi-annual frequency }\end{array}$ \\
\hline$Y_{2}$ & Labour force participation & $\begin{array}{l}\text { OECD statistical } \\
\text { compendium database }\end{array}$ & $\begin{array}{l}\text { Total labour force (LF)/population } \\
\text { in working age ( } 15-64 \text { years old); } \\
\text { semi-annual frequency }\end{array}$ \\
\hline$Y_{3}$ & Currency ratio (M1/M3) & $\begin{array}{l}\text { OECD statistical } \\
\text { compendium database }\end{array}$ & $\begin{array}{l}\text { The frequency is modified from } \\
\text { monthly to semi-annual. Values are } \\
\text { missing from } 1965 \text { to } 1980 \text { and from } \\
1998 \text { to } 2003 \\
\text { For Greece the missing values are } \\
\text { from } 1965 \text { to } 1980 \text { and from to } 2000 \\
\text { to } 2003 \text { Money supply M1-SA/ } \\
\text { money supply M3-SA }\end{array}$ \\
\hline
\end{tabular}

\section{Appendix B: Analysis of normality}

The following Table 9 presents the tests of normality (univariate) of the variables used in the MIMIC models ( $p$ value of the Jarque-Bera Test, performed by Eviews 4.1). For the tests of multivariate normality distribution, the results are reported in Tables 2, 3 and 4.

The sample size is approximately 80 .

\section{Appendix C: Analysis of non-stationarity}

In this appendix we display the tests employed to detect the order of integration in the time series. The pioneer in tackling the problem of non-stationarity in 
Table 9 Jarque-Bera test ( $p$ value)

\begin{tabular}{llcc}
\hline Causes & France & Spain & Greece \\
\hline$\Delta$ [Direct taxation/GDP] & 0.000 & 0.000 & 0.185 \\
$\Delta$ [Indirect taxation/GDP] & 0.000 & 0.146 & 0.052 \\
$\Delta$ [SS. contributions/GDP] & 0.000 & 0.001 & 0.080 \\
$\Delta$ [Public employment/labour force] & 0.548 & 0.126 & 0.000 \\
$\Delta$ [Unemployment rate] & 0.860 & 0.145 & 0.000 \\
$\Delta$ [Self-employment/labour force] & 0.000 & 0.001 & 0.000 \\
Indicators & & & 0.112 \\
$\Delta$ LN[Real GDP per capita] & 0.000 & 0.484 & 0.000 \\
$\Delta$ [Part ratio/labour force] & 0.029 & 0.233 & $0.038^{\mathrm{a}}$ \\
$\Delta \Delta$ [Currency ratio (M1/M3)] & 0.067 & 0.763 & \\
\hline
\end{tabular}

Note: ${ }^{\text {a }}$ The transformation is the first difference

the MIMIC models has been Giles (1995). As Giles and Tedds (2002) point out, the most appropriate way "...to consider the non-stationary element is to consider the possibility of cointegration. Unfortunately, there is no established literature which may serve as a guide to this procedure in the context of the MIMIC model".

To discover the unit roots, the augmented Dickey-Fuller (ADF) test and the Philliphs-Perron (PP) test are used; to choose a number of lags sufficient to remove serial correlation in the residuals and the automatic selection of bandwidth we have employed the Schwarz information criterion (ADF) and the Newey-West test using Bartlett Kernel (PP). In the following tables the $p$ value of the abovementioned tests is reported, while the null hypothesis is the presence of the unit root, and therefore a value greater than 0.05 indicates non-stationary time series.

A third unit root test is applied, namely the Kwiatkowski, Phillips, Schmidt and Shin test (KPSS, Kwiatkowski et al. 1992). ${ }^{23}$ This test differs from the others in that the series is assumed to be (trend-) stationary, according to the null hypothesis. The successive tables show the statistical test, and therefore if the estimated values exceed the respective critical values, ${ }^{24}$ stationarity must be rejected. The critical values for the LM test statistics are based upon the asymptotic results presented in KPSS (Table 1, p. 166).

- KPSS test equation with constant critical values are: $0.347(10 \%), 0.463$ (5\%), 0.739 (1\%);

- KPSS test equation with constant and trend: 0.119 (10\%), 0.146 (5\%), 0.216 (1\%).

The econometric software Eviews 4.1 was used in to perform this analysis.

\footnotetext{
23 The Kernel function was chosen according to Bartlett's criteria and the Newey-West method is used for bandwidths.

24 As the ADF and KPSS tests are adversely sensitive to the presence of breaks in the data, by showing critical values it is possible to check these values with Kurozumi's (2002) critical values (Table 3, p. 86). Kurozumi's (op. cit.) modified KPSS test allow to consider the distortion in the statistical test distribution caused by a structural break.
} 
France

\begin{tabular}{|c|c|c|c|c|c|c|c|c|c|c|}
\hline \multirow{2}{*}{$\begin{array}{l}\text { Variable } \\
\text { Causes }\end{array}$} & \multirow{2}{*}{$\begin{array}{l}\text { Included } \\
\text { in equat. }\end{array}$} & \multicolumn{3}{|l|}{ Level } & \multicolumn{3}{|c|}{ First difference } & \multicolumn{3}{|c|}{ Second difference } \\
\hline & & ADF & PP & KPSS & $\mathrm{ADF}$ & PP & KPSS & $\mathrm{ADF}$ & PP & KPSS \\
\hline Direct tax/GDP & $\mathrm{T} \& \mathrm{C}$ & 0.957 & 0.579 & $0.141 *$ & 0.000 & 0.000 & $0.049 *$ & 0.000 & 0.000 & $0.104 *$ \\
\hline Public emp./lab. force & $\mathrm{T} \& \mathrm{C}$ & 0.999 & 0.999 & 0.257 & 0.000 & 0.009 & $0.141 *$ & 0.001 & 0.000 & 0.202 \\
\hline Indirect tax/GDP & $\mathrm{C}$ & 0.097 & 0.099 & $0.166^{*}$ & 0.029 & 0.000 & $0.226^{*}$ & 0.000 & 0.000 & $0.215 *$ \\
\hline Self empl./lab. force & $\mathrm{T} \& \mathrm{C}$ & 0.817 & 0.889 & 0.200 & 0.000 & 0.000 & $0.112 *$ & 0.000 & 0.000 & $0.122 *$ \\
\hline Unemployment rate & $\mathrm{T} \& \mathrm{C}$ & 0.969 & 0.980 & 0.229 & 0.001 & 0.011 & $0.105^{*}$ & 0.000 & 0.000 & 0.167 \\
\hline SS. contrib./GDP & $\mathrm{T} \& \mathrm{C}$ & 0.983 & 0.994 & 0.297 & 0.000 & 0.001 & 0.151 & 0.000 & 0.000 & 0.213 \\
\hline
\end{tabular}

Note: For ADF and PP show the MacKinnon (1996) one-sided $p$ values; the statistical tests are shown for KPSS; *means stationary at 0.05 level
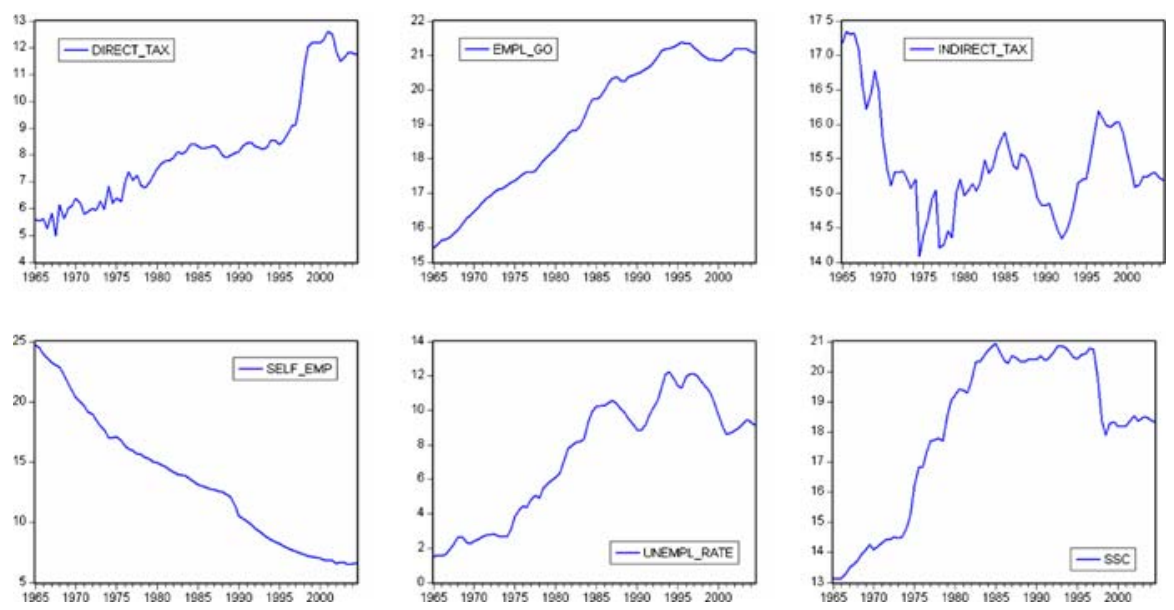

\begin{tabular}{|c|c|c|c|c|c|c|c|c|c|c|c|c|c|}
\hline \multirow{2}{*}{$\begin{array}{l}\text { Variable } \\
\text { Indicators }\end{array}$} & \multirow{2}{*}{$\begin{array}{l}\text { Included } \\
\text { in equat. }\end{array}$} & \multicolumn{3}{|l|}{ Level } & \multicolumn{3}{|c|}{ First difference } & \multicolumn{3}{|c|}{ Second difference } & \multicolumn{3}{|c|}{ First differ. $\log N$} \\
\hline & & $\mathrm{ADF}$ & $\mathrm{PP}$ & KPSS & $\mathrm{ADF}$ & $\mathrm{PP}$ & KPSS & $\mathrm{ADF}$ & $\mathrm{PP}$ & KPSS & $\mathrm{ADF}$ & $\mathrm{PP}$ & KPSS \\
\hline $\begin{array}{l}\text { Real GDP } \\
\text { per capita }\end{array}$ & $\mathrm{T} \& \mathrm{C}$ & 0.529 & 0.485 & $0.123 *$ & 0.000 & 0.000 & $0.134 *$ & 0.000 & 0.000 & 0.358 & 0.000 & 0.000 & 0.168 \\
\hline $\begin{array}{l}\text { Curr. ratio } \\
\text { (M1/M3) }\end{array}$ & $\mathrm{T} \& \mathrm{C}$ & 0.873 & 0.986 & $0.132 *$ & 0.104 & 0.221 & 0.193 & 0.000 & 0.000 & 0.256 & 0.084 & 0.196 & 0.192 \\
\hline $\begin{array}{l}\text { Part. ratio } \\
\text { Lab. force }\end{array}$ & $\mathrm{T} \& \mathrm{C}$ & 0.422 & 0.970 & 0.200 & 0.000 & 0.000 & $0.140 *$ & 0.000 & 0.000 & 0.326 & - & - & - \\
\hline
\end{tabular}

Note: For ADF and PP show the MacKinnon (1996) one-sided $p$ values; the statistical tests are shown for KPSS; *means stationary at 0.05 level
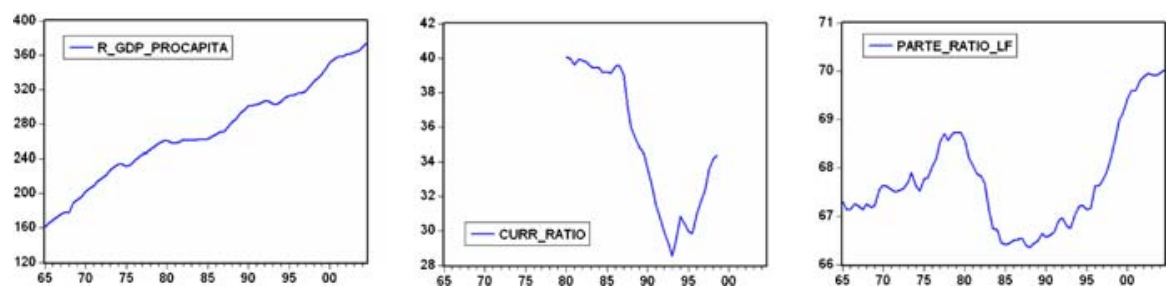
Spain

\begin{tabular}{|c|c|c|c|c|c|c|c|c|c|c|}
\hline \multirow{2}{*}{$\begin{array}{l}\text { Variable } \\
\text { Causes }\end{array}$} & \multirow{2}{*}{$\begin{array}{l}\text { Inlcluded } \\
\text { in equat. }\end{array}$} & \multicolumn{3}{|l|}{ Level } & \multicolumn{3}{|c|}{ First difference } & \multicolumn{3}{|c|}{ Second difference } \\
\hline & & $\mathrm{ADF}$ & PP & KPSS & $\mathrm{ADF}$ & $\mathrm{PP}$ & KPSS & $\mathrm{ADF}$ & PP & KPSS \\
\hline Dil & $C$ & 0.730 & 0.935 & 0.180 & 0.019 & 0.000 & 0.182 & 0.000 & 0.000 & $0.125^{*}$ \\
\hline Public emp./lab. force & $\mathrm{T} \& \mathrm{C}$ & 0.989 & 0.969 & 0.246 & 0.000 & 0.000 & 0. & 0.000 & 0.000 & 0.500 \\
\hline Indirect taxation/GDP & $\mathrm{T} \& \mathrm{C}$ & 0.736 & 0.857 & 0.281 & 0.000 & 0.000 & $0.057 *$ & 0.000 & 0.000 & 0.151 \\
\hline Self-employ./lab. force & $\mathrm{T} \& \mathrm{C}$ & 0.780 & 0.780 & 0.207 & 0.000 & 0.000 & $0.084 *$ & 0.000 & 0.000 & 0.202 \\
\hline Unemployment rate & $\mathrm{T} \& \mathrm{C}$ & 0.642 & 0.897 & 0.201 & 0.084 & 0.069 & $0.084 *$ & 0.000 & 0.000 & $0.032 *$ \\
\hline SS. contrib./GDP & $\mathrm{T} \& \mathrm{C}$ & 0.378 & 0.690 & $0.134 *$ & 0.026 & 0.005 & 0.200 & 0.000 & 0.000 & $0.127 *$ \\
\hline
\end{tabular}

Note: For ADF and PP show the MacKinnon (1996) one-sided $p$ values; the statistical tests are shown for KPSS; *means stationary at 0.05 level
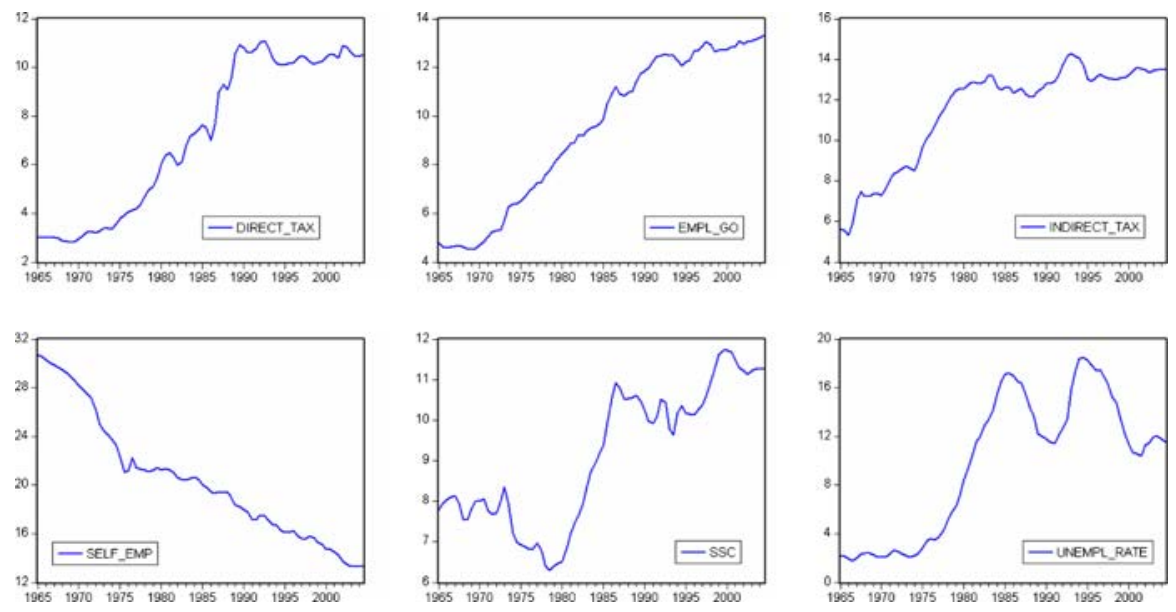

\begin{tabular}{|c|c|c|c|c|c|c|c|c|c|c|c|c|c|}
\hline \multirow{2}{*}{$\begin{array}{l}\text { Variable } \\
\text { Indicators }\end{array}$} & \multirow{2}{*}{$\begin{array}{l}\text { Included } \\
\text { in equat. }\end{array}$} & \multicolumn{3}{|l|}{ Level } & \multicolumn{3}{|c|}{ First difference } & \multicolumn{3}{|c|}{ Second difference } & \multicolumn{3}{|c|}{ First differ. $\log N$} \\
\hline & & $\mathrm{ADF}$ & $\mathrm{PP}$ & KPSS & $\mathrm{ADF}$ & PP & KPSS & $\mathrm{ADF}$ & $\mathrm{PP}$ & KPSS & $\mathrm{ADF}$ & $\mathrm{PP}$ & KPSS \\
\hline $\begin{array}{l}\text { Real GDP } \\
\text { per capita }\end{array}$ & $\mathrm{T} \& \mathrm{C}$ & 0.677 & 0.823 & 0.147 & 0.042 & 0.042 & 0.154 & 0.000 & 0.000 & $0.051 *$ & 0.054 & 0.051 & 0.185 \\
\hline $\begin{array}{r}\text { Curr. ratio } \\
\text { (M1/M3) }\end{array}$ & $\mathrm{C}$ & 0.106 & 0.256 & $0.094 *$ & 0.120 & 0.298 & $0.279 *$ & 0.000 & 0.000 & 0.500 & - & - & - \\
\hline $\begin{array}{l}\text { Part. ratio } \\
\text { lab. force }\end{array}$ & $\mathrm{T} \& \mathrm{C}$ & 1.000 & 1.000 & 0.287 & 0.002 & 0.002 & 0.202 & 0.000 & 0.000 & $0.069 *$ & - & - & - \\
\hline
\end{tabular}

Note: For ADF and PP show the MacKinnon (1996) one-sided $p$ values; the statistical tests are shown for KPSS; *means stationary at 0.05 level
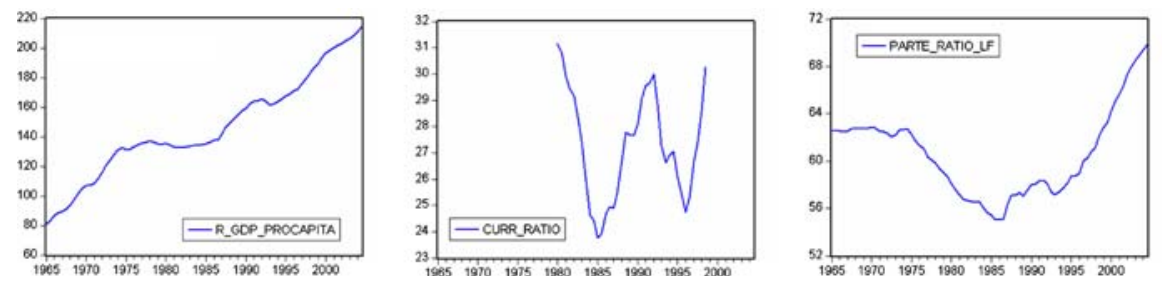
Greece

\begin{tabular}{|c|c|c|c|c|c|c|c|c|c|c|}
\hline \multirow{2}{*}{$\begin{array}{l}\text { Variable } \\
\text { Causes }\end{array}$} & \multirow{2}{*}{$\begin{array}{l}\text { Included } \\
\text { in equat. }\end{array}$} & \multicolumn{3}{|l|}{ Level } & \multicolumn{3}{|c|}{ First difference } & \multicolumn{3}{|c|}{ Second difference } \\
\hline & & ADF & PP & KPSS & $\mathrm{ADF}$ & $\mathrm{PP}$ & KPSS & $\mathrm{ADF}$ & $\mathrm{PP}$ & KPSS \\
\hline Direct taxation/GDP & $\mathrm{T} \& \mathrm{C}$ & 0.004 & 0.605 & 0.187 & 0.258 & 0.000 & $0.070 *$ & 0.545 & 0.000 & $0.145^{*}$ \\
\hline Public empl./lab. force & $\mathrm{T} \& \mathrm{C}$ & 0.927 & 0.895 & 0.245 & 0.001 & 0.061 & $0.042 *$ & 0.000 & 0.000 & 0.500 \\
\hline Indirect tax/GDP & $\mathrm{T} \& \mathrm{C}$ & 0.066 & 0.552 & $0.117 *$ & 0.031 & 0.033 & $0.091 *$ & 0.000 & 0.000 & 0.225 \\
\hline Self empl./lab. force & $\mathrm{T} \& \mathrm{C}$ & 0.001 & 0.311 & $0.041 *$ & 0.005 & 0.000 & 0.249 & 0.000 & 0.000 & $0.097 *$ \\
\hline Unemployment rate & $\mathrm{T} \& \mathrm{C}$ & 0.146 & 0.422 & 0.147 & 0.056 & 0.146 & $0.132 *$ & 0.000 & 0.000 & $0.070^{*}$ \\
\hline SS. contrib./GDP & $\mathrm{T} \& \mathrm{C}$ & 0.075 & 0.155 & $0.064 *$ & 0.002 & 0.099 & $0.054 *$ & 0.002 & 0.000 & $0.131 *$ \\
\hline
\end{tabular}

Note: For ADF and PP show the MacKinnon (1996) one-sided $p$ values; the statistical tests are shown for KPSS; *means stationary at 0.05 level
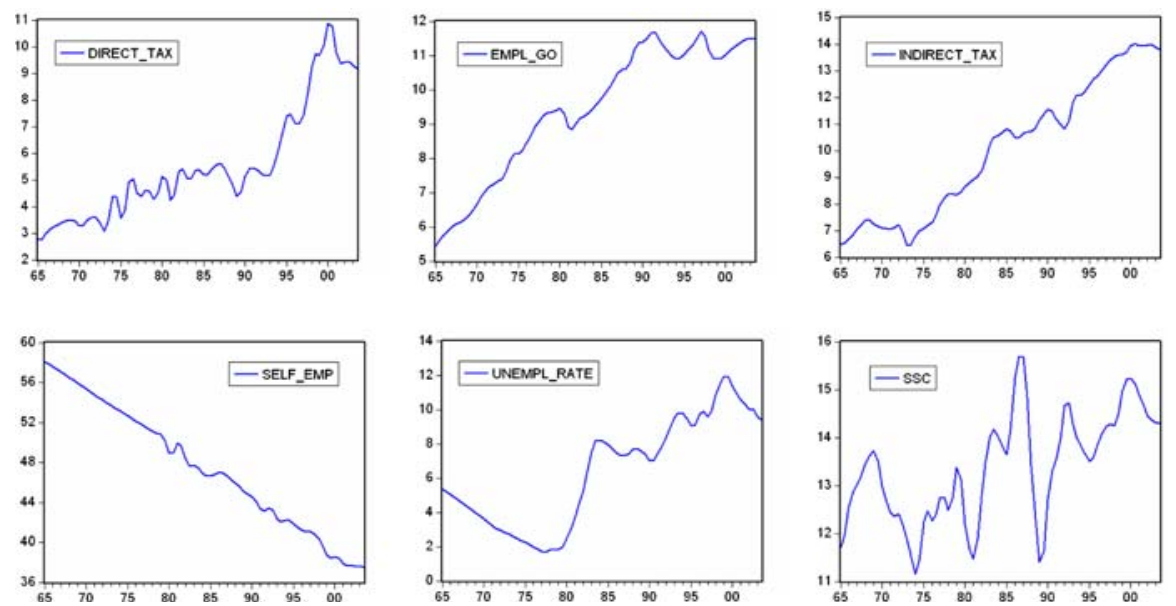

\begin{tabular}{|c|c|c|c|c|c|c|c|c|c|c|c|c|c|}
\hline \multirow{2}{*}{$\begin{array}{l}\text { Variable } \\
\text { Indicators }\end{array}$} & \multicolumn{3}{|c|}{$\begin{array}{l}\text { Included Level } \\
\text { in equat. }\end{array}$} & \multicolumn{4}{|c|}{ First difference } & \multicolumn{3}{|c|}{ Second difference } & \multicolumn{3}{|c|}{ First differ. $\log N$} \\
\hline & & $\mathrm{ADF}$ & $\mathrm{PP}$ & KPSS & $\mathrm{ADF}$ & $\mathrm{PP}$ & KPSS & $\mathrm{ADF}$ & PP & KPSS & $\mathrm{ADF}$ & $\mathrm{PP}$ & KPSS \\
\hline $\begin{array}{l}\text { Real GDP } \\
\text { per capita }\end{array}$ & $\mathrm{T} \& \mathrm{C}$ & 0.130 & 0.683 & 0.174 & 0.378 & 0.035 & 0.243 & 0.000 & 0.000 & 0.229 & 0.457 & 0.047 & 0.262 \\
\hline $\begin{array}{c}\text { Curr. ratio } \\
\text { (M1/M3) }\end{array}$ & $\mathrm{T} \& \mathrm{C}$ & 0.129 & 0.003 & 0.198 & 0.054 & 0.003 & 0.202 & 0.000 & 0.000 & 0.391 & - & - & - \\
\hline $\begin{array}{l}\text { Part. ratio } \\
\text { lab. force }\end{array}$ & $\mathrm{C}$ & 0.572 & 0.228 & $0.401 *$ & 0.001 & 0.002 & $0.342^{*}$ & 0.000 & 0.000 & $0.146^{*}$ & - & - & - \\
\hline
\end{tabular}

Note For ADF and PP show the MacKinnon (1996) one-sided $p$ values; the statistical tests are shown for KPSS; *means stationary at 0.05 level
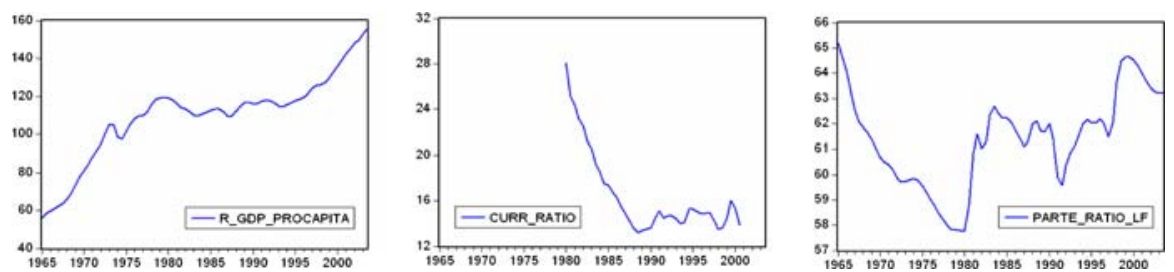


\section{Appendix D: Analysis of residuals}

In this appendix, the q-plots of residuals are shown in order to verify the normal distribution of the residuals ${ }^{25}$ of the MIMIC models chosen for the French, Spanish and Greek shadow economies. Unfortunately, there are several limitations upon the precise identification of the properties of the residuals, especially in when there are missing values in the data. Below, the $q$-plots produced by the Lisrel 8.54 software are reported. These graphs show a sufficiently normal distribution of residuals.

\section{Q-plots of residuals}
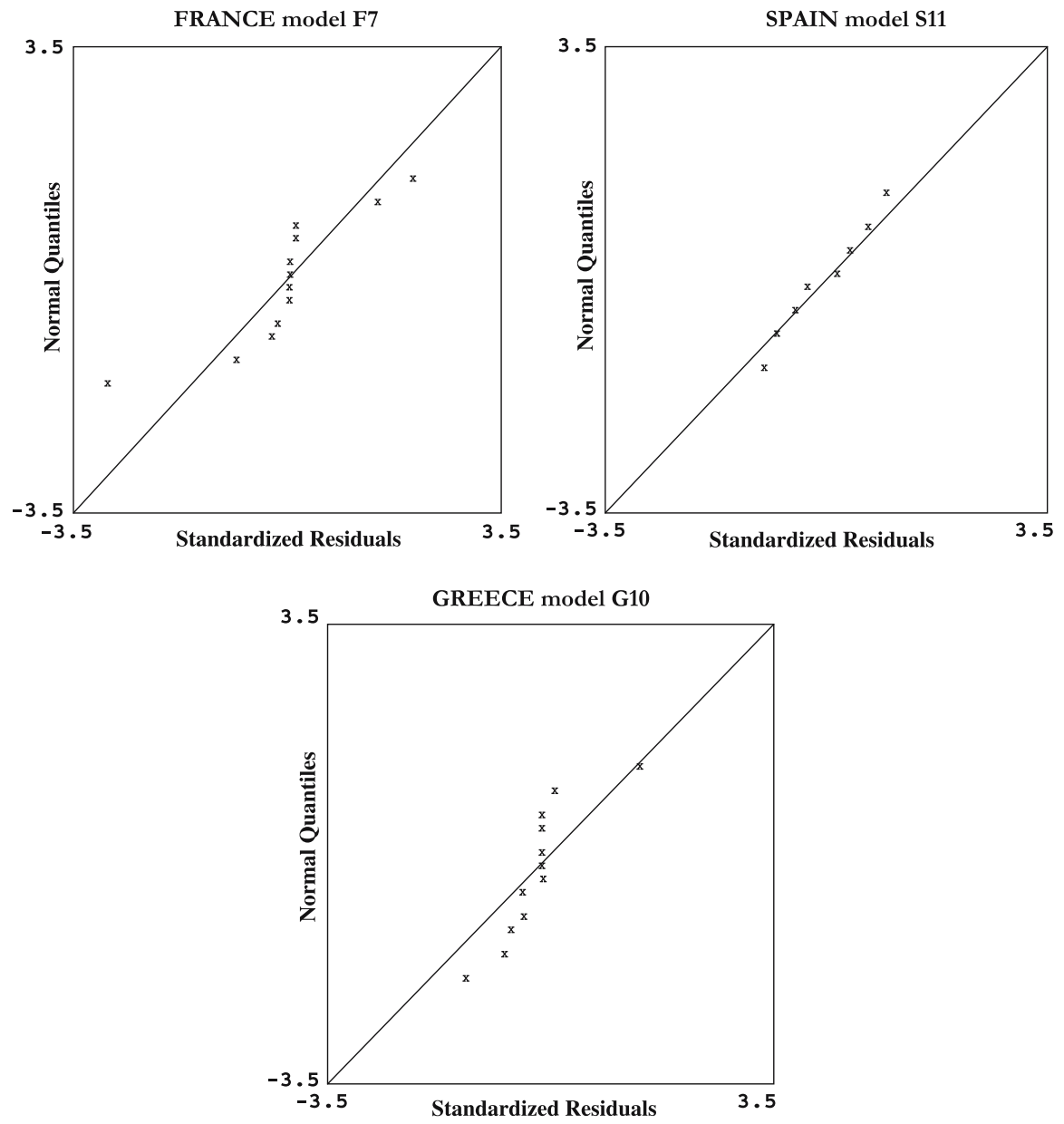

25 In LISREL terminology a "residual" is the difference between an observed and fitted covariance. 


\section{Appendix E: Simulated effects of economic policies on the SE for 2003}

France

Elasticities:

- Reductions of direct tax rate by $10 \%$ (from 11.7 to $10.6 \%$ ) would reduce the SE by $8.1 \%$ (that is 0.7 -percentage point: from 9.1 to $8.4 \%$ ).

- Reductions of unemployment rate by $10 \%$ (from 9.4 to $8.4 \%$ ) would reduce the SE by $14.5 \%$ (that is 1.4 -percentage point: from 9.2 to $7.8 \%$ ).

- Reductions of self-employment rate by $10 \%$ (from 6.6 to $5.9 \%$ ) would reduce the SE by $29.9 \%$ (that is 1.7 -percentage point: from 9.2 to $7.5 \%$ ).

Level effects:

- Reductions of direct tax rate by 1-percentage point (from 11.7 to $10.7 \%$ ) would reduce the SE by 0.6-percentage point (from 9.1 to $8.5 \%$ ).

- Reductions of unemployment rate by 1-percentage point (from 9.4 to $8.4 \%$ ) would reduce the SE by 1.5-percentage point (from 9.1 to $7.6 \%$ ).

- Reductions of self-employment rate by 1-percentage point (from 6.6 to $5.6 \%$ ) would reduce the SE by 2.5-percentage point (from 9.1 to $6.6 \%$ ).

Spain

Elasticities:

- Reductions of indirect tax rate by $10 \%$ (from 11.3 to $10.1 \%$ ) would reduce the SE by $2.9 \%$ (that is 0.8 -percentage point: from 27.3 to $26.5 \%$ ).

- Reductions of social security contribution rate by $10 \%$ (from 13.5 to $12.1 \%$ ) would reduce the SE by $4.4 \%$ (that is 1.2 -percentage point: from 27.3 to $26.1 \%)$.

- Reductions of public employment rate by $10 \%$ (from 13.1 to $11.8 \%$ ) would reduce the SE by $4.8 \%$ (that is 1.3 -percentage point: from 27.3 to $26.0 \%$ ).

- Reductions of unemployment rate by $10 \%$ (from 12.0 to $10.8 \%$ ) would reduce the SE by $4.4 \%$ (that is 1.2 -percentage point: from 27.3 to $26.1 \%$ ).

Level effects:

- Reductions of indirect tax rate by 1-percentage point (from $11.3 \%$ to $10.3 \%$ ) would reduce the SE by 0.9-percentage point (from $27.3 \%$ to $26.4 \%$ ). Reductions of public employment rate by 1-percentage point (from $13.1 \%$ to $12.1 \%$ ) would reduce the SE by 2.0-percentage point (from $27.3 \%$ to $25.3 \%$ ).

- Reductions of social security contribution rate by 1-percentage point (from $13.5 \%$ to $12.5 \%$ ) would reduce the SE by 0.6-percentage point (from $27.3 \%$ to $26.7 \%$ ).

- Reductions of unemployment rate by 1 percentage point (from $12.0 \%$ to $11.0 \%$ ) would reduced the SE by 1.0 -percentage point (from $27.3 \%$ to $26.3 \%$ ). 


\section{Greece}

Elasticities:

- Reductions of social security contribution rate by $10 \%$ (from 13.8 to $12.5 \%$ ) would reduce the SE by $20.5 \%$ (that is 5.5 -percentage point: from 26.7 to $21.2 \%$ ).

- Reductions of unemployment rate by $10 \%$ (from 9.5 to $8.4 \%$ ) would reduce the SE by $7.8 \%$ (that is 2.1-percentage point: from 26.7 to $24.6 \%$ ).

- Reductions of self-employment rate by $10 \%$ (from 37.6 to $33.8 \%$ ) would reduce the SE by $18.7 \%$ (that is 5.0 -percentage point: from 26.7 to $21.7 \%$ ).

Level effects:

- Reductions of social security contribution rate by 1-percentage point (from 13.8 to $12.8 \%$ ) would reduce the SE by 4.0-percentage point (from 26.7 to $22.7 \%)$.

- Reductions of unemployment rate by 1-percentage point (from 9.5 to $8.5 \%$ ) would reduce the SE by 2.2-percentage point (from 26.7 to $24.5 \%$ ).

- Reductions of self-employment rate by 1-percentage point (from 37.6 to $36.6 \%$ ) would reduce the SE by 1.2-percentage point (from 26.7 to $25.5 \%$ ).

\section{References}

Adam M, Ginsburgh CV (1985) The effects of irregular markets on macroeconomic policy: some estimates for Belgium. Eur Econ Rev 29: 15-33

Ahn N, De la Rica S (1997) The underground economy in Spain: an alternative to unemployment? Appl Econ 29:733-743

Aigner DJ Schneider F, Ghosh D (1988) Me and my shadow: estimating the size of the U.S. hidden economy from time series data. Dynamic econometric modelling. In: Berndt $\mathrm{E}$, White $\mathrm{H}$, Barnett W (eds) Proceedings of the third international symposium in economic theory and econometrics. Cambridge University Press, Cambridge, pp 297-334

Alañón A, Gómez-Antonio M (2005) Estimating the size of the shadow economy in Spain: a structural model with latent variables. Appl Econ 37:1011-1025

Baldini N, Cherubini U (1998) Yield curve movements and market segmentation: a LISREL analysis of the Italian case. Econ Notes 27:35-54

Bajada C, Schneider F (2005) The shadow economies of the Asia-Pacific. Pac Econ Rev 10 (3):379401

Barthelemy P (1989) The underground economy in France in the underground economies: tax evasion and information distortion. Cambridge University Press, Cambridge

Bentler PM (1986) Structural equation modelling and psycometrika: an historical perspective on growth and achievements. Psycometrika 51:35-51

Bielby WT, Hauser M (1977) Structural equation models. Annu Rev Sociol 3:137-161

Blank RM (1994) Social protection versus economic flexibility: is there a trade off? National Bureau of Economic Research Comparative Labor Markets Series, University of Chicago Press, Chicago

Bollen KA (1989) Structural equations with latent variables. Wiley, New York

Bordignon M, Zanardi A (1997) Tax evasion in Italy. Giornale degli Economisti e Annali di Economia Volume 56:169-210

Brandstatter E, Brandstatter H (1996) What's money worth? Determinants of the subjective value of money. J Econ Psychol 17:443-464

Breitung J (2001) A convenient representation for structural vector autoregressions. Empir Econ 26:447-459

Brumm H (1997) Military spending, government disarray, and economic growth: a cross-country empirical analysis. J Macroecon 19:827-838 
Brumm H, Cloninger D (1995) Violent crime and punishment: an application of the LISREL model. Appl Econ 27:719-725

Byrne BM (1998) Structural equation modelling with LISREL, PRELIS, and SIMPLIS. Multivariate applications book series. Mahwah Lawrence Erlbaum Associates, Hillsdale

Cassar A (2001) An index of the underground economy in Malta. Bank Valletta Rev 23:44-62

Chatterjee S, Chaudhuri K,.Schneider F (2003) The size and development of the Indian shadow economy and a comparison with 18 other Asian countries: an empirical investigation. Working paper 2003-02. Department of Economics, Johannes Kepler University, Linz

Christopoulos DK (2003) Does the underground economy respond symmetrically to tax changes? Evidence from Greece. Econ Model 20:563-570

D’Agostino RB (1986) Tests for the normal distribution. In: D'Agostino RB, Stephens MA (eds) Goodness-of-fit techniques. Marcel Dekker, New York, pp 367-419

De Grazia R (1983) Le travail clandestin: situation dans les pays industrialiés économie de marché. Bit, Geneve

Dell'Anno R (2003) Estimating the shadow economy in Italy: a structural equation approach. University of Aarhus, Department of Economics, DK. Working paper 2003-7

Dell'Anno R, Schneider F (2003) The shadow economy of Italy and other OECD countries: what do we know? J Public Financ Public Choice 21:97-120

Duncan OD (1975) Introduction to structural equation models. Academic, New York

Eijffinger S, Hoeberichts M, Schaling E (2000) Optimal central bank conservativeness in an open economy. Public Choice 105:339-355

Eilat Y, Zinnes C (2000) The evolution of the shadow economy in transition countries: consequences for economic growth and donor assistance. CAER II discussion paper no. 83, Harvard Institute for International Development

EUROSTAT (2003) EC economic data pocket book, European Commission, Luxemburg, pp 7-8

Frey B, Weck-Hanneman H (1984) The hidden economy as an "unobservable" variable. Eur Econ Rev 26:33-53

Gadea M, Serrano-Sanz JM (2002) The hidden economy in Spain-a monetary estimation 1964-1998. Empir Econ 27:499-527

Gerpott T, Rams W, Schindler A (2001) Customer retention, loyalty, and satisfaction in the German mobile cellular telecommunications market. Telecomm Policy 25:249-269

Giles DEA (1995) Measuring the size of the hidden economy and the tax gap in New Zealand: an econometric analysis. Working paper no. 5a, Working paper on monitoring the health of the tax system, Inland Revenue Department, Wellington

Giles DEA (1998) The underground economy: minimizing the size of government. Working Paper, Department of Economics, University of Victoria, Victoria

Giles DEA (1999a) Measuring the hidden economy: implications for econometric modeling. Econ J 109:370-380

Giles DEA (1999b) Modelling the hidden economy in the tax-gap in New Zealand. Working Paper, Department of Economics, University of Victoria, Victoria

Giles DEA, Tedds LM (2002) Taxes and the Canadian underground economy. Canadian Tax paper 106. Canadian Tax Foundation, Toronto

Goldberger AS (1972) Structural equation methods in the social sciences. Econometrica 40: 979-1001

Gómez-Antonio M, Alañón A (2004) Evaluación y análisis espacial del grado de incumplimiento fiscal para las provincias españolas. Hacienda Pública Española/Revista de Economía Pública 171:9-32

Hauser R, Sewell W (1986) Family effects in simple models of education, occupational status, and earnings: findings from the Wisconsin and Kalamazoo studies. J Labor Econ 4:83-115

Hayduk LA (1987) Structural equation modelling with LISREL. Essentials and advances. John Hopkins University Press, London

Helberger C, Knepel H (1988) How big is the shadow economy? A re-analysis of the unobservedvariable approach of B.S. Frey and H. Weck-Hannemann. Eur Econ Rev 32:965-976

Hoyle RH (ed) (1995) Structural equation modelling: concepts, issues, and applications. Sage, Thousand Oaks

Ihrig J, Moe KS (2000) The influence of government policies on informal labor: implications for long run growth. The Economist 148:331-343 
Ihrig J, Moe KS (2001) Tax policies and informal employment: the Asian experience. Asian Econ J 15:369-383

Ihrig J, Moe KS (2004) Lurking in the shadows: the informal sector and government policy. J Dev Econ 73:541-557

Jaccard J, Wan CK (1996) The LISREL approach to interaction effects in multiple regression. Quantitative applications in the social science. Sage University paper. SAGE publications, London

Johnson S, Kaufmann D, Zoido-Lobatón P (1998a) Regulatory discretion and the unofficial economy. Am Econ Rev 88:387-392

Johnson S, Kaufmann D, Zoido-Lobatón P (1998b) Corruption, public finances and the unofficial economy. World Bank Discussion Paper

Jöreskog K, Goldberger AS (1975) Estimation of a model with multiple indicators and multiple causes of a single latent variable. J Am Stat Assoc 70:631-639

Jöreskog K, Sörbom D (1993) LISREL 8, user's reference guide. Scientific Software International, Chicago

Kanellopoulos K, Kousoulakos I, Rapanos B (1995) Underground economy and tax evasion: measueres and economic impact, Report 15, Centre of Planning and Economic Research, Athens

Kaufmann D, Kaliberda A (1996) Integrating the unofficial economy into the dynamics of postsocialist economies. Policy research working paper 1691. World Bank, Washington

Kurozumi E (2002) Testing for stationarity With a break. J Econom 108:63-99

Kwiatkowski D, Phillips PCB, Schmidt P, Shin Y (1992) Testing the null hypothesis of stationarity against the alternative of a unit root. J Econom 54:159-178

Lafuente A (1980) Una medición de la economía oculta en España. Boletín de Estudios Económi$\cos 111: 581-593$

Leibfritz W, O'Brien P (2005) The French tax system: main characteristics, recent developments and some considerations for reform. Economic working paper (2005)26, OECD

Loayza NV (1996) The economics of the informal sector: a simple model and some empirical evidence from Latin America. Carnegie-Rochester Conference Series on Public Policy 45:129-162

MacKinnon JG (1996) Numerical distribution functions for unit root and cointegration tests. J Appl Econom 11:601-618

Mardia KV (1970) Measures of multivariate skewness and kurtosis with applications. Biometrika 57:519-530

Maruyama GM (1997) Basics of structural equation modeling. SAGE Publications, Thousand Oaks

Mauleón I, Sardá J (1997) Estimación cuantitativa de la economía sumergida en España. Ekonomiaz 39:125-135

Moltó MA (1980) La economía irregular. Una primera aproximación al caso español. Revista Española de Economía 10:33-52

Pindyck R, Rotemberg J (1993) The comovement of stock prices. Quart J Econ 108:1073-1104

Pozo S (ed.) (1996) Exploring the underground economy. Studies of illegal and unreported activity. Institute for Employment Research, Michigan, W.E. Upjohn

Prokhorov A (2001) The Russian underground economy as a "Hidden" variable. Presented at Midwest Slavic Conference, Cleveland, March 29-31

Rettig K, Leichtentritt R, Danes S (1999) The effects of resources, decision making and decision implementation on perceived family well-being in adjusting to an economic stressor. J Family Econ Issues 20:5-34

Ruesga SM (1984) Economia oculta y mercado de trabajo: Aproximación al caso español. Informacion Comercial Española 607:55-61

Schneider F (1997) The shadow economies of Western Europe. Econ Aff 173:42-48

Schneider F (2004) The size of the shadow economies of 145 Countries all over the world: first results over the period 1999-2003. IZA discussion paper series 1431

Schneider F (2005) Shadow economies around the world: what do we really know? Eur J Polit Econ 21:598-642

Schneider F, Enste D (2000) Shadow economies: size, causes, and consequences. J Econ Lit 38:77-115

Stapleton DC (1978) Analyzing political participation data with a MIMIC Model. Sociol Methodol 15:52-74

Tanzi V (1999) Uses and abuses of estimates of the underground economy. Econ J 109:338-347 
Tatsos N (2001) Underground economy and tax evasion in Greece, Foundation for economic and industrial research (IOBE), Papazissis, Athens

Tedds LM (1998) Measuring the size of the hidden economy in Canada. MA extended essay, University of Victoria, Department of Economics, Victoria

Tedds LM (2006) The underground economy in Canada. In: Bajada C, Schneider F (eds) Size, causes and consequences of the underground economy. Ashgate, Aldershot

Thomas J (1992) Informal economic activity. Handbooks in Economics, Harvester Wheatsheaf, London

Zellner A (1970) Estimation of regression relationships containing unobservable variables. Int Econ Rev 11:441-454 
Copyright of Empirical Economics is the property of Springer Science \& Business Media B.V. and its content may not be copied or emailed to multiple sites or posted to a listserv without the copyright holder's express written permission. However, users may print, download, or email articles for individual use. 
Copyright of Empirical Economics is the property of Springer Science \& Business Media B.V. and its content may not be copied or emailed to multiple sites or posted to a listserv without the copyright holder's express written permission. However, users may print, download, or email articles for individual use. 